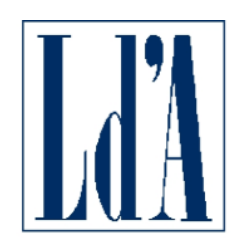

CENTRO STUDI LUCA D'AGLIANO

WWW.DAGLIANO.UNIMI.IT

CENTRO STUDI LUCA D'AGLIANO

DEVELOPMENT STUDIES WORKING PAPERS

N. 420

January 2017

Migrant labor in the Norwegian petroleum sector

Bernt Bratsberg*

Oddbjфrn Raaum*

Ole Rogeberg*

* Frisch Centre 
December 15, 2015

\title{
Migrant labor in the Norwegian petroleum sector
}

\author{
Bernt Bratsberg, Oddbjørn Raaum, and Ole Rogeberg
}

Frisch Centre

\begin{abstract}
:
Drawing on comprehensive sets of administrative register data, we examine employment and pay structures in the Norwegian petroleum sector between 1992 and 2013, with a particular emphasis on foreign workers. The period covers a number of important changes taking place, with rising oil prices and growing investments during the 2000s and a large influx of labor migrants into Norwegian labor markets following the 2004 expansion of the European Union. Relative to foreign workers in other private-sector industries, we find that the petroleum sector is characterized by greater use of posted workers, a higher occupational skill mix of immigrants, and, for those in skilled occupations, wages on par with native workers. Migrant petroleum workers have shorter durations in the country than other migrants, and the data reveal only modest job mobility to other industries, particularly among high-skilled workers. Nonetheless, the evidence points to spillover effects from the petroleum sector as workers who move on to jobs in mainland industries earn a wage premium relative to those without petroleum experience.
\end{abstract}

Acknowledgments: This paper is prepared within the "Value Added in Motion (VAM)" project funded by the Enel Foundation. We also acknowledge funding from the Norwegian Research Council (project 233687:

"Prospects for Norwegian Petroleum Extraction and implications for the Norwegian Economy as a whole"). We are grateful for valuable comments from Giovanni Facchini, Tommaso Frattini, and seminar participants at the University of Milan and Statistics Norway. The paper is part of the research activities of the Centre of Equality, Social Organization, and Performance, University of Oslo. Data made available by Statistics Norway have been essential for this research. 


\section{Introduction}

Natural resource wealth can become a major, shaping influence on a nation's economy, which makes it important to understand both the benefits and the drawbacks of such endowments. Globally, natural resource endowments are correlated with reduced economic growth, the so-called "resource curse" (Sachs and Warner 2001). A prominent worry is the so-called "Dutch disease," whereby extraction and sale of natural resources cause suffocation of other export-oriented businesses and make the economy overly dependent on an exhaustible resource with often volatile prices (Bruno and Sachs 1982; Corden and Neary 1982). On the converse side, the "resource curse" seems related to weak political institutions (Mehlum, Moene, and Torvik 2006), making it a lesser concern in Western economies. Empirical studies also uncover positive effects on manufacturing growth in regions close to resource-abundant areas (Allcott and Keniston 2014), and there may be positive human capital effects from multinational companies operating in a highly competitive global market. Indeed, prior research has found positive wage spillovers as workers with experience from multinationals move on to other firms or industries (Balsvik 2011; Poole 2013), with potential implications for individual wage profiles (Møen 2007).

In this paper, we examine employment and pay structures in the Norwegian petroleum sectors, with a particular emphasis on the sector's use of foreign workers. These are expected to have a particular importance in the petroleum sector as this sector differs from the rest of the Norwegian private sector economy along a number of dimensions. Specifically, operators are often large, international companies operating in multiple locations globally, and served by a network of knowledge-intensive suppliers and sub-contractors. Labor market treaties, such as that of the European Economic Area, allowing for higher-thanelsewhere shares of foreign workers in resource-intensive sectors would be one way of preventing the resource movement aspect of Dutch disease. Inflows of foreign workers might mitigate the tendency for private sector wages to be bid up by a petroleum sector in need of more labor (Beine et al 2015). Has this resulted in a higher share of labor migrants and temporary foreign workers in these sectors relative to other private-sector industries? And to what extent does the petroleum sector serve as a potential "point-of-entry" for skilled immigrants that later move out of the petroleum sector and into other parts of the Norwegian economy? Finally, are there spillover effects from worker mobility from the 
petroleum sector to the mainland economy, whereby those with experience from the hightech petroleum sector bring knowledge externalities that raise the productivity of coworkers in their new firm ${ }^{1}$

\section{A brief history of the petroleum sector in Norway}

We study employment in the years 1992-2013, a period during which the Norwegian petroleum sector underwent rapid and major change. Following three decades of growth, oil extraction peaked around the turn of the millennium and shifted into a steady decline (see Figure 1). Norwegian gas production, on the other hand, increased throughout the entire study period.

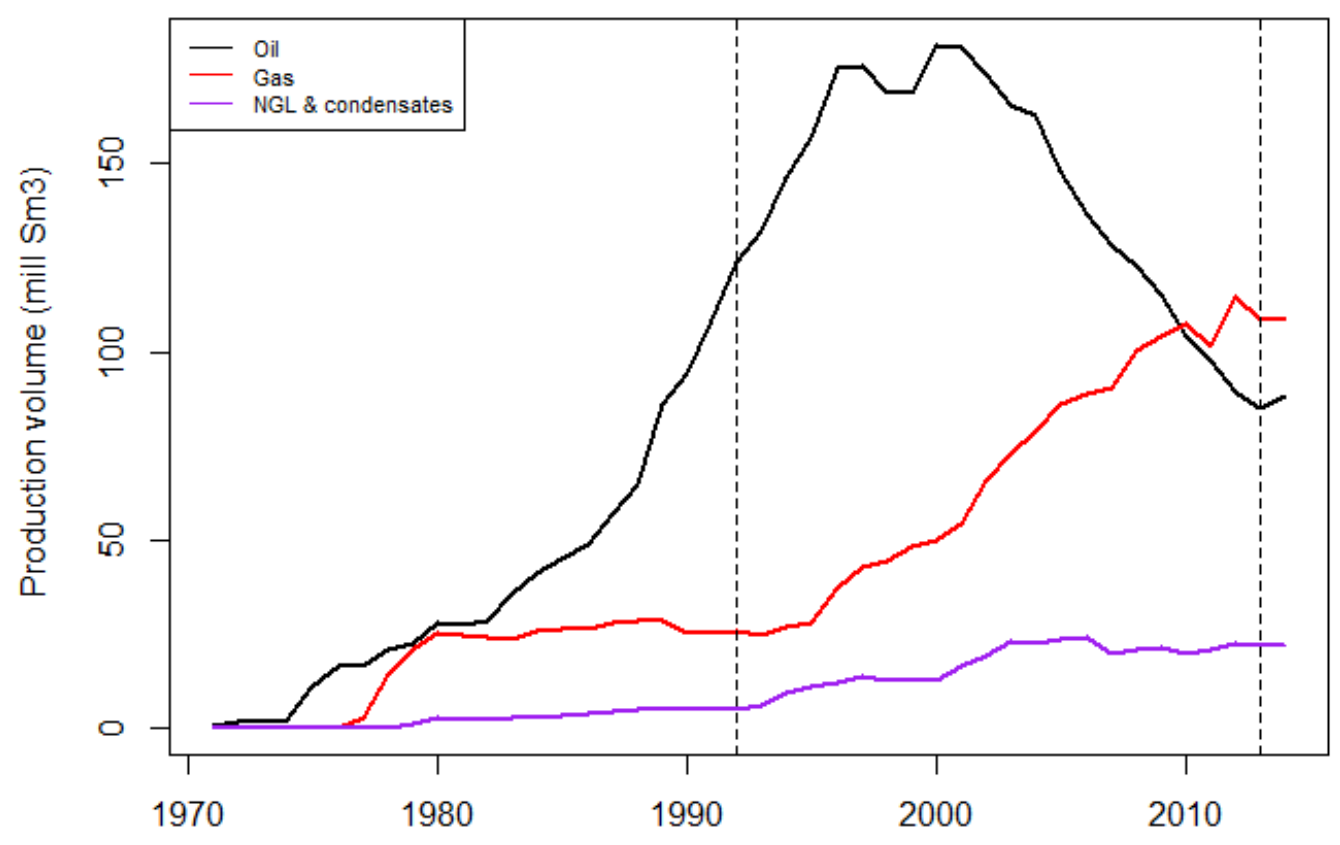

Figure 1 - Extraction of oil, natural gas, and NGL and condensates, 1970-2014

Note: The unit is Millions Sm3 oil equivalents per year. Our study period (1992-2013) is marked with dshed vretical lines. Source: The Norwegian Petroleum Directorate

\footnotetext{
${ }^{1}$ The presence of spillover effects is a basic premise for a number of theoretical studies in the resource literature (e.g., Olsen and Osmundsen 2003), but empirical investigations of such effects remain scarce. An exception is Bjørnland and Thorsrud (2015), who, drawing on aggregated data and a dynamic factor model approach, conclude that "... a booming resource sector has significant and positive productivity spillovers on non-resource sectors."
} 
A second major change concerned the oil price, which had remained stable around 20 USD per barrel throughout the nineties. Around the year 2000, prices began a climb that eventually brought them past the 100 USD mark in 2010 (see Figure 2). ${ }^{2}$ The price increase was accompanied by a marked increase in investment, reaching levels above 200 billion NOK in 2013 and 2014 (25 billion Euros using 2014 exchange rates). This sharp investment increase was likely amplified by a strengthening of the investment incentives in the Norwegian tax system.

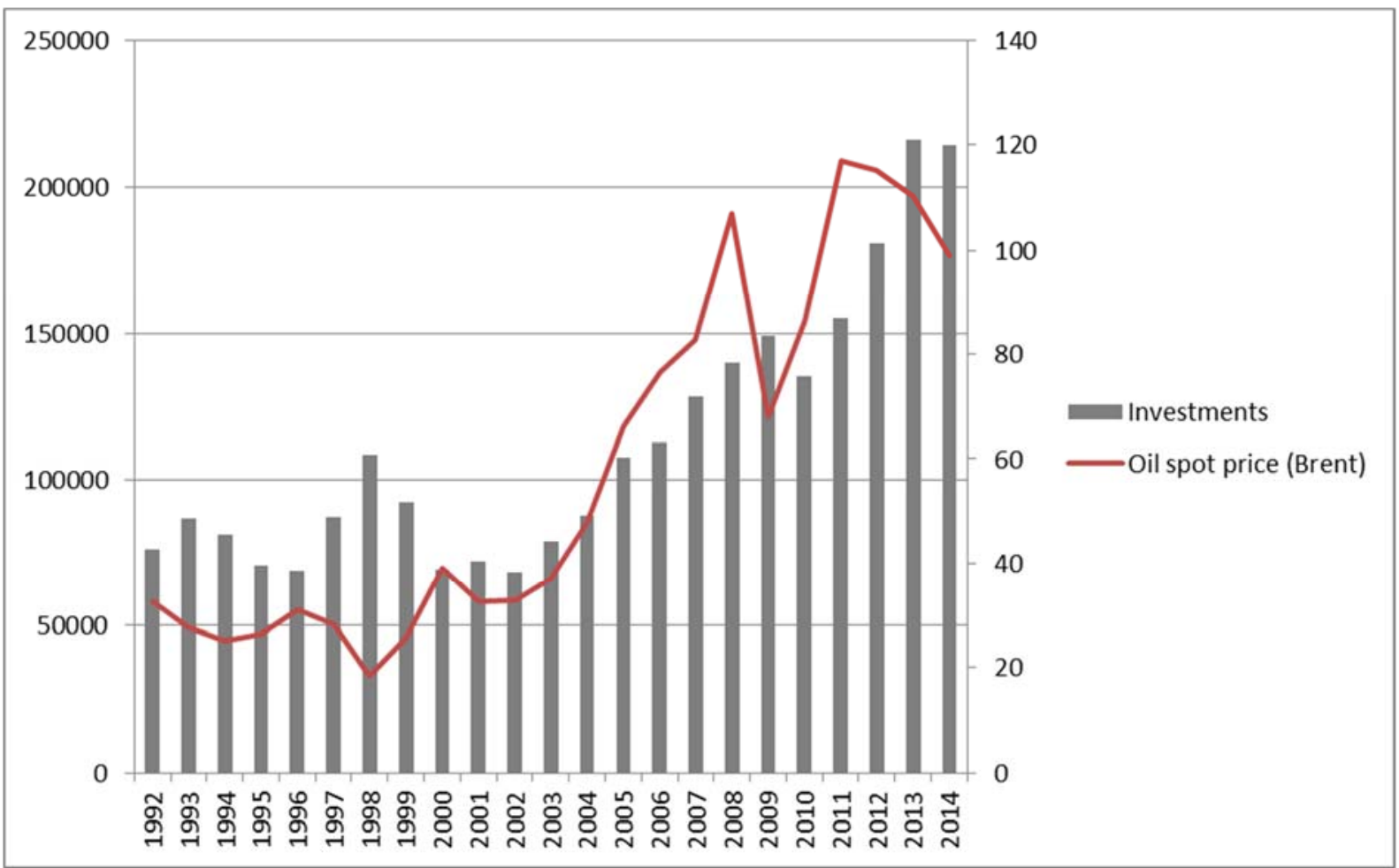

Figure 2 - Oil price and investments in the Norwegian petroleum sector, 1992-2014

Note: The price is for Brent - spot crude price. Investments are in 2014 million NOK. Source: BP statistical review 2014 and the Norwegian Petroleum Directorate.

\footnotetext{
${ }^{2}$ We focus on oil prices despite the growing importance of natural gas for the Norwegian petroleum economy. Unlike oil, gas prices are usually negotiated within long-term delivery contracts, and these are often indexed to the oil price. Being dependent on gas pipelines, these prices also tend to show more variation across geographically distinct regions, with LNG (Liquid Natural Gas) serving as an imperfect link between markets. This regional variation has been especially evident in the last decade, where increasing production of shale gas has caused natural gas prices to fall in North America while Europe continued to see prices rise in a pattern that qualitative matched the oil price rise.
} 
To place these changes in context, we briefly review the history of the Norwegian petroleum industries. $^{3}$

In 1962 Philips, the oil company, asked Norwegian authorities for permission to conduct seismic tests in the North Sea. In the following years, Norway made territorial demands on the continental shelf and negotiated dividing lines with the UK and Denmark. Having established claims over an area almost equal to the area of the mainland, the second half of the sixties was characterized by exploratory drilling with mostly disappointing results up to the discovery of the large "Ekofisk" field late 1969.

The Ekofisk discovery raised interest in the Norwegian continental shelf from existing oil majors. In addition to its financial value, Norwegian authorities also emphasized the potential of the new sector as a tool for industrial development. A Norwegian state-owned oil company, Statoil, was founded in 1973 and given large shares of the prospects that were made available throughout the decade. US operators were used to train and build the capabilities needed for the new company to operate in the field. Norwegian authorities also worked to establish a strong, Norwegian supplier industry. Norwegian shipyards and the shipping industry provided a base for this, while Statoil's preferential use of Norwegian suppliers ensured a rising demand for services and technologies from the mainland.

Initially, the offshore sector was dominated by US operators that tended to have a negative attitude towards organized labor, as well as hazardous working conditions that resulted in 82 deaths between 1965 and 1978. This led to a series of changes in the way working conditions were regulated, a process that culminated in the working environment act being expanded to cover all offshore activities in 1993.

Returning to the seventies, the increasing presence of Norwegian workers offshore led to a heightened level of conflict between operators and unions, resulting in a number of strikes in the last years of the decade. This tension persisted to a lesser extent throughout the eighties.

Another political goal, formulated explicitly by Parliament in 1974, was to avoid an unbalanced growth in the petroleum sector relative to the mainland economy. This was

\footnotetext{
${ }^{3}$ This section draws in large part on the exposition in Ryggvik (2014) and Holden (2013).
} 
closely related to fears of a "Dutch disease," a term originally coined by the Economist in 1977 which refers to the structural distortion of the economy that results from booms of the kind generated by natural resource exploitation (Corden and Neary 1982). First, as a booming sector bids up the price of required inputs that are not internationally traded (as was the case, to a large extent, with labor), this creates a resource movement effect that raises input prices for other sectors in the economy. Secondly, as revenues are spent on domestic services and non-traded goods, this raises their price relative to traded goods (termed the spending effect). Both mechanisms raise domestic wages and prices, causing a real appreciation of the currency and a weakening of other export-oriented industries. As a result, the economy becomes increasingly dependent on revenues from the natural resource, and a painful adjustment period results when extraction (or prices) fall.

While the different parties were to disagree on what this entailed, Parliament would refer to the need for a "moderate" pace of extraction up until the end of the eighties. As Norway prepared to enter the European Economic Area (EEA), however, a number of political changes took place: Protectionist measures that gave priority to Norwegian companies and Norwegian industry were removed, and foreign companies were given more access to the continental shelf. The desire for a moderate pace of extraction was also abandoned, as the establishment of an oil fund ("The Norwegian Government Pension Fund") investing proceeds in international financial instruments served to "decouple" the pace of extraction from the domestic use of the resulting funds. This should be seen in combination with the later introduction of a broadly supported fiscal rule stating that only the real return (set at $4 \%)$ of the pension fund should be available for spending. "Thus, the Pension Fund and the fiscal rule would ensure that the large, volatile and temporary net cash flow from the petroleum sector is transferred to a stable supplement to the government budget" (Holden 2013).

As a result of these changes, activity increased rapidly throughout the nineties, making Norway the third largest exporter of oil and gas around the turn of the century. Following this, however, Norwegian oil production entered a stark decline, with oil production falling by $50 \%$ between 2000 and 2013, while gas production continued at high levels. Norwegian authorities worked to counteract the overall decline from around 2002, providing easier access to prospects, allowing for between-company trades in block-shares, and providing tax 
incentives for increased exploration. The result was a strong increase in investments, which overall tripled in real terms between 2000 and 2013, and which resulted in a number of new discoveries in 2010 and 2011 (Cappelen et al 2013).

Looking forward from the present, the Norwegian Petroleum Directorate projects continued extraction around current levels. At the same time, the halving of the crude oil price through the latter half of 2014 has led to reduced investments and brought concerns that declining petroleum sector activity and employment will create negative demand shocks for the mainland economy.

\section{Data}

Our analyses draw on micro data from Norwegian administrative registers, made available for research purposes by Statistics Norway. There are two primary datasets. One is the linked employer-employee register that contains information from all payroll records submitted by employers to Norwegian tax authorities in the period 1992-2013, with individual and firm identifiers allowing us to match payroll data to other datasets. From 2003, these data also contain information on occupation, as reported by employers, coded using a nationally adjusted variant ("STYRK") of the Eurostat-version ("ISCO88(COM)") of the ILO standard. The second primary dataset contains information on foreign workers with shortterm job contracts in Norway, as reported by employers. These data are obtained from the Central Office-Foreign Tax Affairs (SFU) of the Norwegian Tax Administration, the agency that oversees employment of foreign workers with short-term contracts. The data records include start and stop dates of the work contract as well as identifiers of the client firm and foreign contractor. We use the industry of the (Norwegian-based) client firm in order to assign posted workers to the petroleum sector.

Information on the posted workers is more sparse than that of natives and other immigrants and migrant workers. The posted workers will usually be missing from Norwegian administrative datasets covering education, past work experience, etc., and information on wages will be missing as these workers are paid abroad by the foreign contractor and are not subject to Norwegian taxes. This will be the case, under the terms of the OECD model convention with respect to taxes on income and capital, when the total stay of the worker is less than 183 days per 12-month period, for an employee not based in Norway, at a location 
that is not a permanent establishment operated by their employer, and provided that they are not hired out to other employers. The last condition is judged by the tax authorities using a number of indications. Consider, for instance, a case where firm A hires foreign firm $B$ for some task. The workers of firm $B$ are more likely to be judged as hired out to $A$ if $A$ is operationally in charge of the day-to-day work of B's workers, if A pays an hourly rate for B's workers, if $A$ determines the number and composition of $B^{\prime}$ 's workers, if $A$ carries the main risk of the work result, etc.

Using the firm and individual identifiers, we are able to further characterize firms by industry (i.e., SIC codes) and geographical location (i.e., county) using data based on the Brønnøysund Business Register, while individuals are characterized by their country of birth, immigrant status, education, age and gender using data from the central population register, the register of work permits and the national education database. Here, too, the available data will differ for different categories of workers. In particular, administrative registers will contain less information on non-resident workers. We distinguish between "native" Norwegian workers, resident foreign workers (i.e., immigrants), migrant workers with temporary work permits, and posted workers based abroad and working for foreign firms with contracts in Norway. Finally, we limit all data series to employees (excluding selfemployed) with a job contract during the month of November. For workers with multiple contracts, we retain the job with highest pay or, in the case of posted workers without pay data, the most recent start date.

\section{Petroleum Sector Employment}

\subsection{Trends in employment}

Total employment in the petroleum sectors remained largely stable throughout the nineties, but entered a period of growth with increasing pace after 2000 (see Figure 3). From 46 thousand employees in 2001, total employment had grown by 76 percent to 81 thousand in 2013. In comparison, employment in other private-sector industries grew by 22 percent, from 1.25 to 1.54 million workers, over the same period. The employment growth in the petroleum sector was concentrated in firms classified as providing extraction services, i.e., technology development and drilling of various kinds of oil and gas wells. Surprisingly, in light of the shifting importance of natural gas production relative to oil, the underlying data 
show that extraction of oil still dominated massively in 2013 (about 26,000 employees) relative to extraction of natural gas (about 1,700 employees).

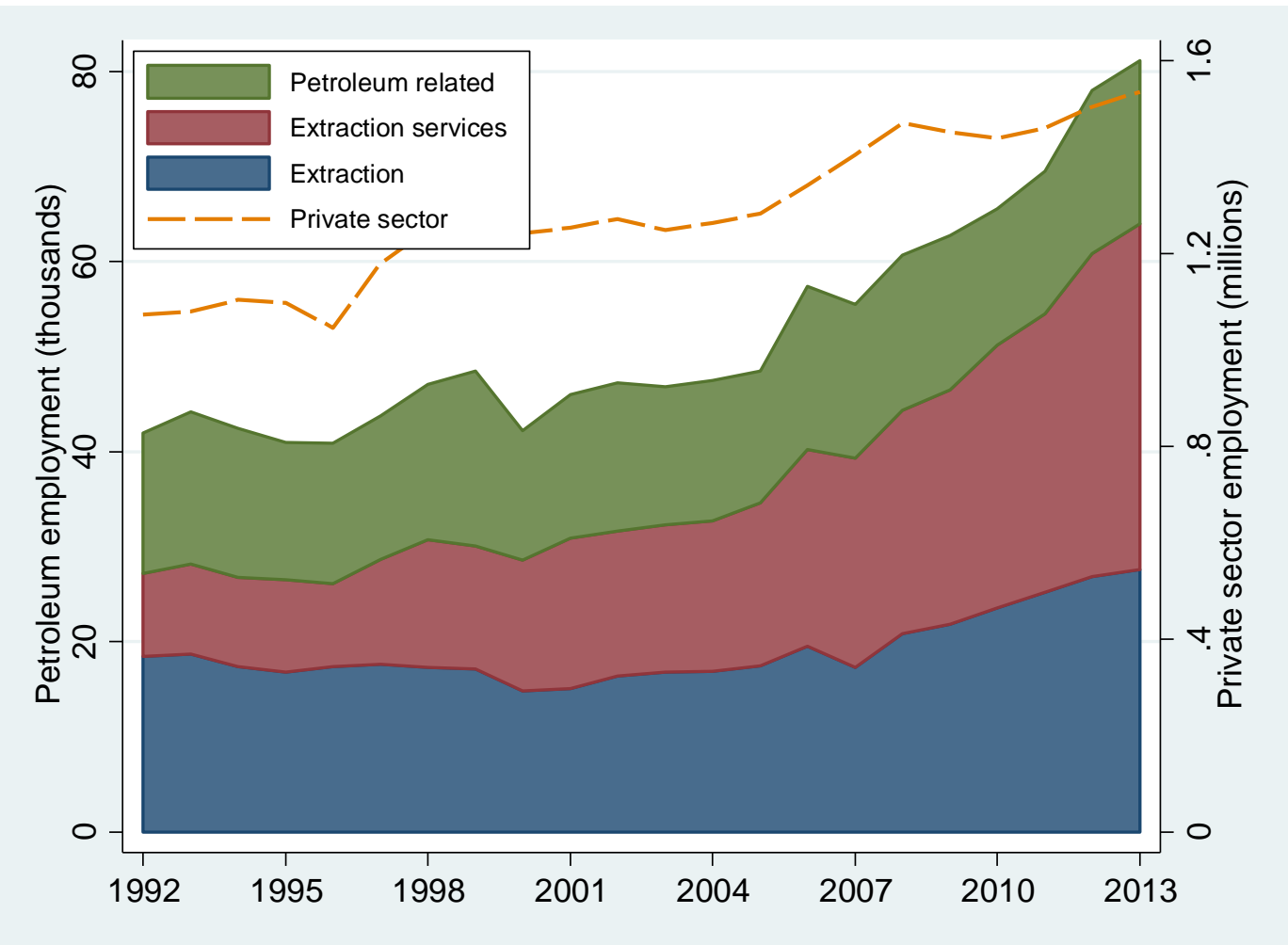

Figure 3 - Trends in employment in petroleum and other private-sector industries, 19922013

Note: Employment figures cover workers with a job in the petroleum sector during the month of November. Source: Authors' tabulations from register data

The classification of the petroleum sector and its industries used in Figure 3 and later follows Statistics Norway (Sandvik and Johannesen 2013). The classification distinguishes between the petroleum industry itself, consisting of firms engaged in extraction of oil and gas on the Norwegian continental shelf, and petroleum related industries "... which produce goods and services targeting the petroleum industry". In our analyses below, we contrast this sector with other private sector workers, and exclude public sector employees. The classification of the petroleum sector does not include firms in the remaining private sector that supply goods and services to the petroleum sector and, in result, we understate the extent of 
petroleum-related activities. ${ }^{4}$ Statistics Norway operationalizes the petroleum sector industries in terms of Standard Industrial Classification (SIC2007) codes, distinguishing between (1) Extraction of crude petroleum and natural gas (code 06000), labelled "Extraction" in figures; (2) Support activities for petroleum and natural gas extraction (09100) and Transport via pipeline (49500), labelled "Extraction services"; and (3) Building of oil platforms and modules (30113), Installation and completion work on platforms and modules (30116) and Offshore supply terminal (52223), labelled "Petroleum related" industries . Following an extensive review of industry codes in 2011, Statistics Norway reassigned some large companies from the petroleum related industry to extraction services, affecting the categorization of their workers between 2009 and 2010. To provide consistent data series, we identify establishments that switched industry codes between 2009 and 2010 and recategorize their employees in the data from earlier years as well.

\subsection{Foreign labor}

For foreign workers, we distinguish between (1) immigrants, (2) temporary migrants and (3) posted workers. Immigrants are defined through their enrollment in the Central population register, i.e., by their filing of an immigration form with the local police as part of the immigration process. With the exception of citizens of the neighboring Nordic countries, enrollment in the population register requires a preapproved immigrant visa issued by the Directorate of Immigration. Citizens of countries with a labor agreement with Norway (such as the European Union), may enter the country and search for a job for up to six months. In general, for citizens of countries with a labor agreement enrollment in the population register is required for those who intend to stay in Norway more than six months.

We identify non-resident foreign workers on short-term contracts from the SFU register described in the prior section, and separate "temporary migrants" from "posted workers" by whether or not the worker appears with an earnings record in the register of the Tax Administration the year of the work contract. Temporary migrants also typically appear in the employer-employee data, allowing us to assess their job information and industry of

\footnotetext{
${ }^{4}$ As discussed by Sandvik and Johannessen (2013), Eika, Prestmo, and Tveter (2010) estimate that, in 2006, 206,000 workers were employed in the extended sector that also accounts for direct and indirect supply to petroleum-related activities. The figure contrasts with the 63,000 workers employed in the narrowly defined sector used in the present paper.
} 
employment directly from the employer. For posted workers, we assign the industry of the Norwegian-registered client to the job contract.

Figure 4 shows trends in foreign employment shares in the petroleum sector and other private-sector industries. While foreign labor in the petroleum sector was more common than in the mainland private economy until 2013 , its role in the petroleum sector increased as the sector grew after 2000 . Overall, the foreign labor share in petroleum was in the $10-15 \%$ range from 1992-2005, increasing to the $17-20 \%$ range in the $2006-2012$ period (see Figure 4). This was due to a sharp increase in the foreign labor share of petroleum related services after 2005 , as well as a more steady growth in the foreign labor share of extraction (see Figure 5). Figure 4 also reveals secular growth in migrant employment in the private sector during the observation period, with the overall migrant employment rate increasing from 3.9 percent in 1992 to 19.3 percent in 2013, overtaking the migrant employment rate in the

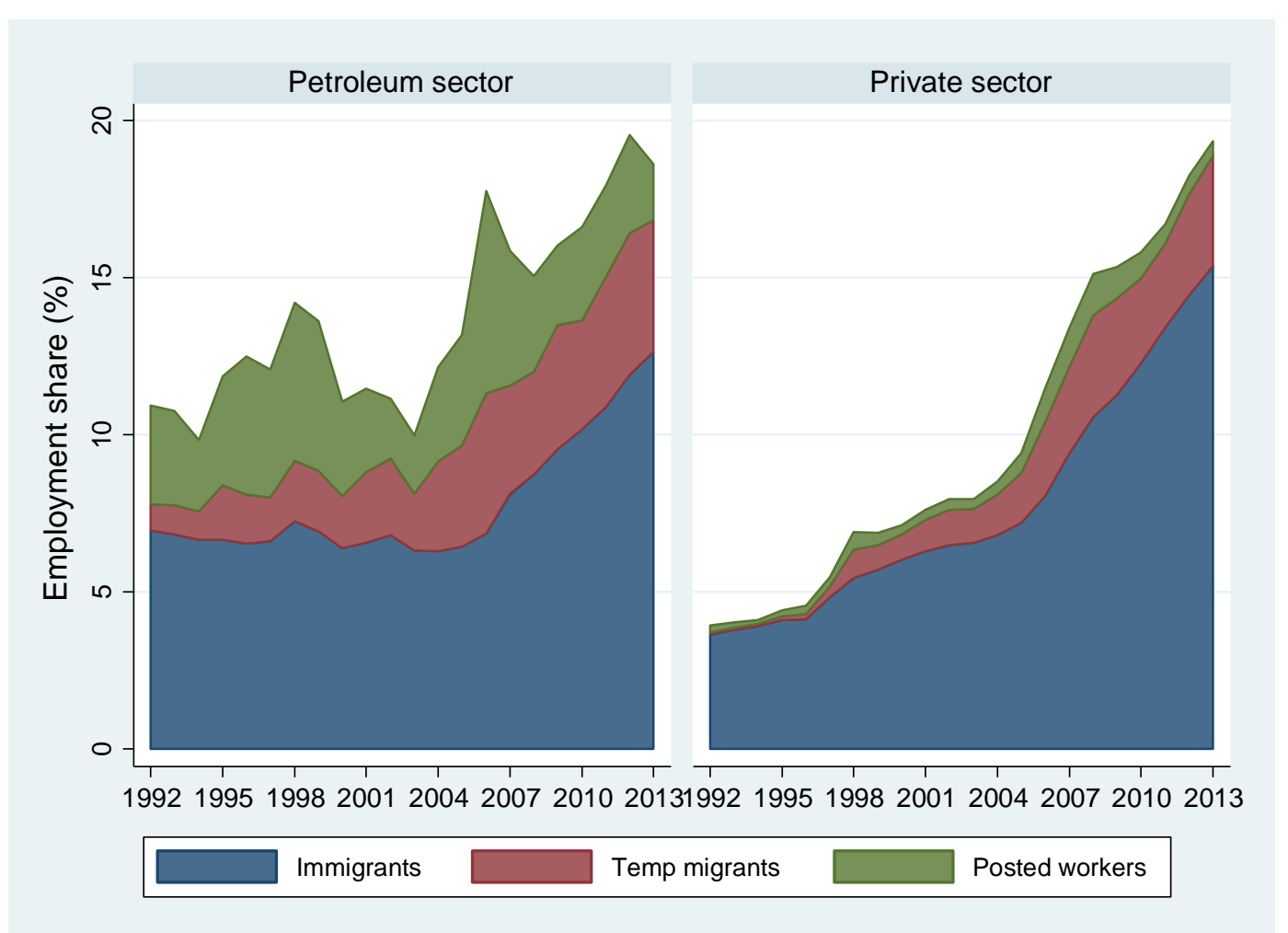

Figure 4 - Foreign employment shares of petroleum and other private sector, 1992-2013 Source: Authors' tabulations from register data 
petroleum sector. While immigrants are the most frequent category of foreign workers in both places, their share of all foreign workers is markedly lower in the petroleum sector (67.9\% vs. $79.5 \%$ on the mainland in 2013). In particular, posted workers are uncommon in the mainland economy ( $2 \%$ of all foreign workers) and more commonly used in the petroleum sector (10\% of foreign workers in 2013). As the figure shows, the share of posted workers in petroleum fluctuates heavily over the sample period. The visible spike in 2006 (36\% of all foreign petroleum workers and $50 \%$ of those in petroleum-related industries) reflects in part the construction of the gas pipeline ("Ormen Lange") between Aukra, Norway and Easington, England.

On average, a majority of the foreign workers have been immigrants with Norwegian residence, but, as shown in Figure 5, this differs markedly between the different petroleum industries and across time. In extraction, comprised of the core activities involved in the

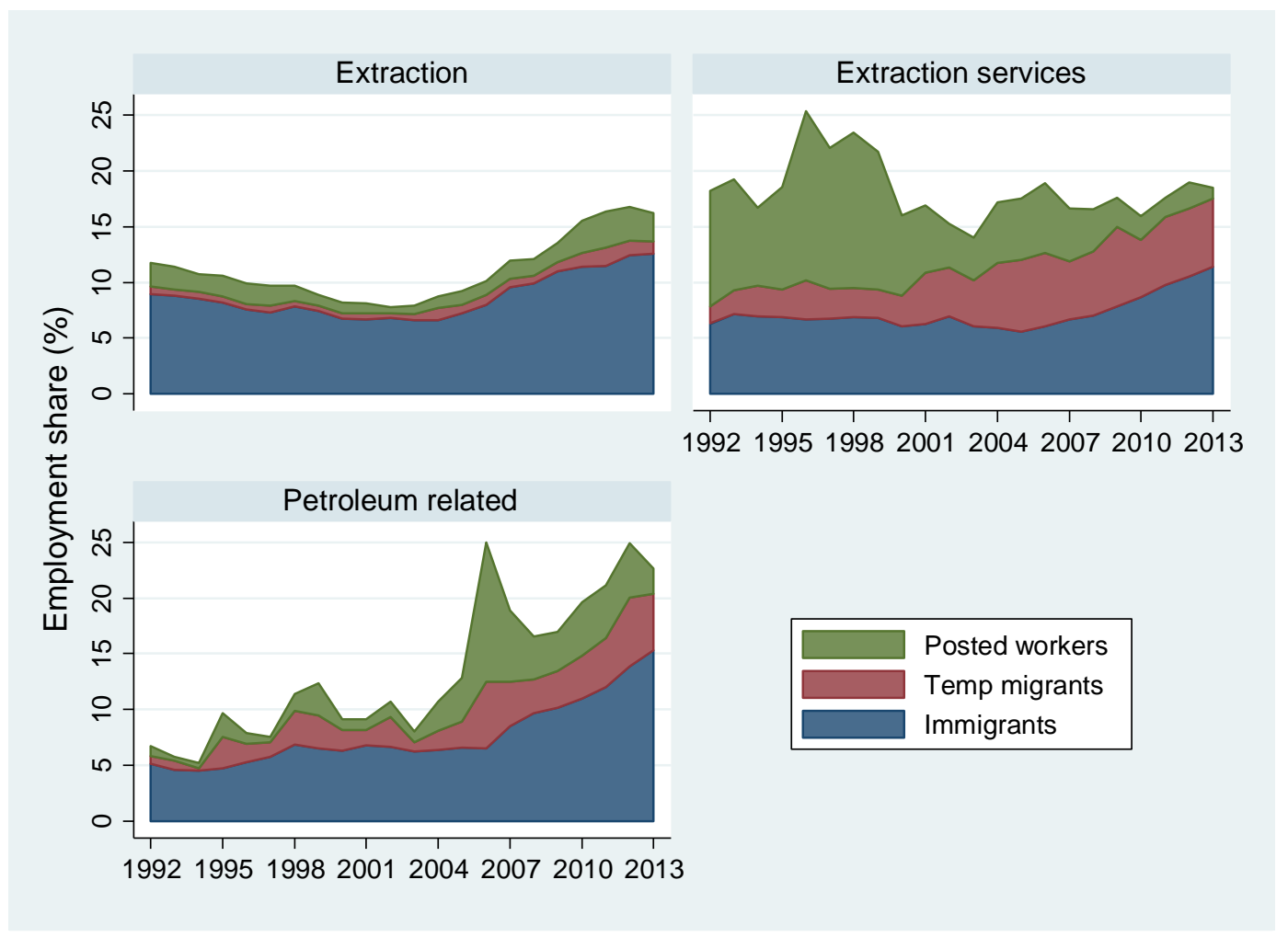

Figure 5 - Foreign employment as share of petroleum sector industries, 1992-2013 
permanent operation of offshore fields, immigrants have been the largest category of foreign workers throughout the period. In extraction services, more related to drilling test wells and establishing new fields, immigrants have usually been a minority of the foreign workers. Across the period as whole, though, extraction services do seem to exhibit a clear trend towards less use of posted workers (foreign workers based abroad working for foreign firms operating in Norway) and more use of temporary migrants (foreign workers without residence in Norway but paid by an employer based in Norway) and - to a lesser extent immigrants. The opposite trend is seen for petroleum related services, which are heavily involved in building and furnishing new oil platforms. In this sector, the foreign worker group was strongly dominated by immigrants in the early parts of the period, and where the trend has been towards an increasing use of posted workers and temporary migrants, particularly after 2004.

\subsection{Country background of foreign workers}

The country background of foreign workers in the petroleum sector differs from that of the private sector. Table 1 shows, for each foreign worker category, the five main countries of origin. Denmark, Poland and Sweden are present as top five countries in most worker categories in both sectors, but with a different weighting: Whereas Poland and Sweden collectively make up $29 \%, 62 \%$ and $31 \%$ of, respectively, immigrants, temporary migrants and posted workers in the private sector, their analogous share in the petroleum sector is less than half of this (14\%, $35 \%$ and $13 \%$ respectively). Denmark, on the other hand, has a stronger relative presence in the petroleum sector. Together with the UK, they make up 17\%, $48 \%$ and $62 \%$ respectively of the immigrant, temporary migrant and posted worker categories in the petroleum sector, with the UK being the top origin country in all three groups of foreign petroleum workers.

In general, the picture is a lower presence of the Eastern European countries relative to the private sector, and a higher presence of the UK, Denmark and Netherlands, along with some Asian nations active in the petroleum sector (India, Philippines). This difference between the petroleum and private sector may reflect the more specific skill set needed in the sector, as well as the presence of international operators recruiting from other markets in which they are active or based. 
Table 1 - Five main countries of origin by migrant status, foreign workers in petroleum and other private sector, 2012

\begin{tabular}{|c|c|c|c|c|c|c|}
\hline \multirow[b]{2}{*}{ Country of origin } & \multicolumn{3}{|c|}{ Petroleum sector } & \multicolumn{3}{|c|}{ Private sector } \\
\hline & Immigrants & $\begin{array}{l}\text { Temporary } \\
\text { migrants }\end{array}$ & $\begin{array}{l}\text { Posted } \\
\text { workers }\end{array}$ & Immigrants & $\begin{array}{l}\text { Temporary } \\
\text { migrants }\end{array}$ & $\begin{array}{l}\text { Posted } \\
\text { workers }\end{array}$ \\
\hline Denmark & 4.9 & 21.1 & 31.0 & 2.9 & 4.2 & 12.2 \\
\hline Germany & & & & 4.2 & & \\
\hline India & 5.3 & & & & & \\
\hline Latvia & & & & & 2.6 & \\
\hline Lithuania & & & & 6.9 & 12.5 & 10.2 \\
\hline Netherlands & & & 2.9 & & & \\
\hline Philippines & & & 6.3 & & & \\
\hline Poland & 7.1 & 14.8 & 12.5 & 19.4 & 26.2 & 14.0 \\
\hline Romania & & 2.9 & & & & \\
\hline Sweden & 6.8 & 19.9 & & 9.4 & 36.1 & 17.4 \\
\hline UK & 11.7 & 26.4 & 31.4 & & & 9.2 \\
\hline Other countries & 64.3 & 14.8 & 15.3 & 57.3 & 18.4 & 37.9 \\
\hline Observations & 9,287 & 3,522 & 2,426 & 217,283 & 48,529 & 8,578 \\
\hline
\end{tabular}

Note: Table entries are the shares of November employment within sector and migrant status.

\subsection{Shocks to labor supply - the roles of the EU expansion and the financial crisis}

The dramatic increase in oil prices after 2000 along with the improved investment tax incentives have both combined to increase the labor force employed in the petroleum sectors. While these factors are expected to raise labor demand, however, other changes have increased labor supply facing the petroleum and non-petroleum sectors during the same period.

The first of these is the enlargements of the European Union, where eight Central and Eastern European countries along with Malta and Cyprus joined the union in 2004 and Bulgaria and Romania followed in 2007. The EU enlargements generated an inflow of labor from low-wage economies into the Norwegian economy (see Figure 6). This increase in labor supply in turn had repercussions throughout the labor market, affecting wage trajectories and employment opportunities for natives in the occupations where foreign workers could compete on skills and qualifications (Bratsberg and Raaum 2012). 


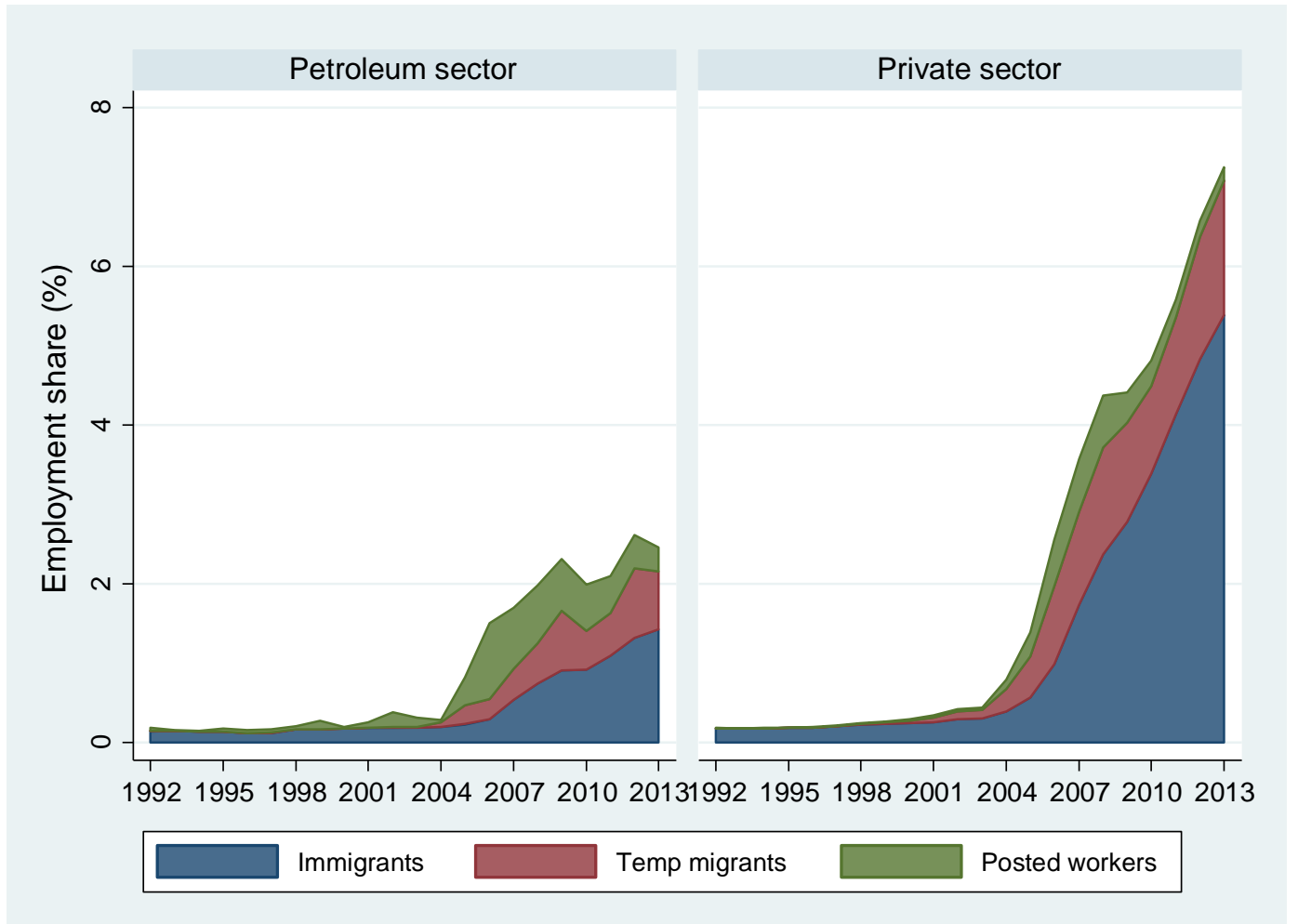

Figure 6 - Employment shares of petroleum and other private sector, workers from new EU member countries in Eastern Europe

Source: Authors' tabulations from register data

The second change that could be expected to have influenced the labor supply is the longlasting economic difficulties in Southern Europe. As shown in Figure 7, this too has been increasing over time since the early nineties, with the stock of workers from Greece, Italy, Spain and Portugal more than doubling between 2005 and 2013 in the mainland private sectors. The absolute number of these was far smaller than the number of workers from the new EU members in Eastern Europe, around a 1:15 ratio. On the other hand, it might be that the qualifications and experience of the Southern European workers differs in such a way that their impact on certain occupations may be discernible all the same.

Turning to the petroleum sectors, we see a stark increase in the labor supply from the new EU member countries following the 2004 EU enlargement, with much of the increase in recent years coming from immigrants and temporary migrants relative to posted workers. The pronounced growth in use of posted workers between 2004 and 2007 revealed by the 
figure stems from Polish workers on contracts with client firms in the platform building and installation industries.

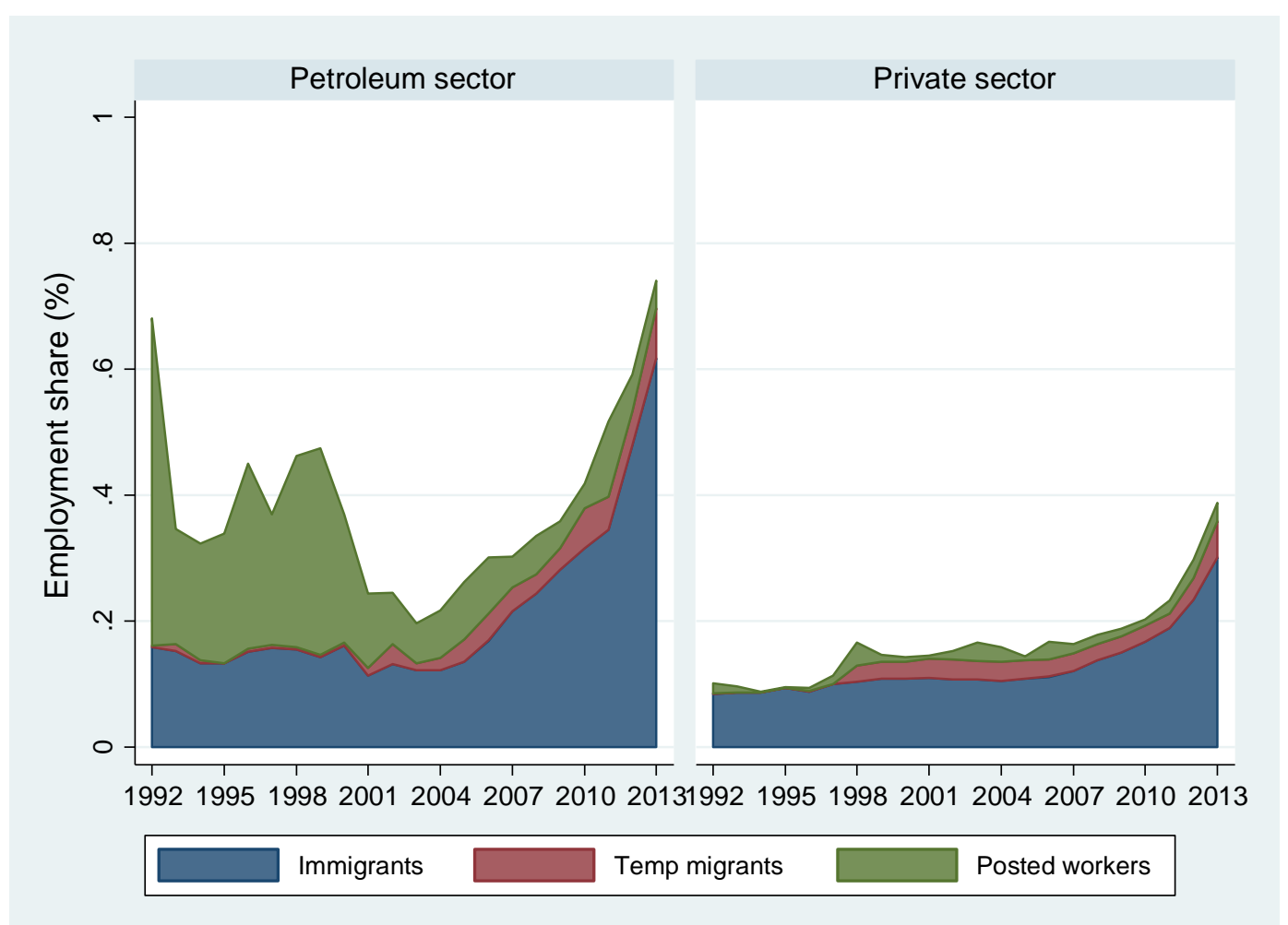

Figure 7 - Employment shares of petroleum and other private sector, workers from Greece, Italy, Portugal and Spain

Source: Authors' tabulations from register data

Looking at the labor stock with country background from the Southern European countries shows no dramatic change in overall numbers over time. These numbers instead evidence a marked shift in the "attachment" of these workers to the Norwegian economy: Whereas these workers tended to be posted workers in the early nineties (the majority of whom were Italian nationals engaged by drilling companies), the clear majority of them are now residents. Indeed, Southern Europeans with residence in Norway form a particularly fast growing component of overall employment in the Norwegian petroleum sector, with a seven-fold increase between 2005 and 2013. The dramatic growth of this population in 
recent years hints that a prolonged crisis in Southern Europe will have a significant influence on future labor supply facing the Norwegian petroleum sector.

\section{Skills and wages in the petroleum sector}

This section describes core elements of the skill and wage structures in the petroleum sector in 2013. To place the petroleum sector in perspective, we make comparisons with immigrants and natives working in the rest of the private sector. Petroleum sector workers differ from other private sector employees along a number of dimensions. In Table 2 we report workers characteristics for foreign and native workers by sector. ${ }^{5}$

In general, foreign workers are younger than natives in both the petroleum and other private-sector industries, except for temporary migrants who are of the same age as natives in the petroleum sector. The petroleum sector is dominated by men, but the female share is slightly higher among immigrants than natives (23.3\% vs $20.4 \%$ ). Female employment shares are higher in the private sector, $37.0 \%$ among natives and $37.7 \%$ among immigrants. Very few of the temporary migrant workers are female; only $3.0 \%$ in petroleum and $11.4 \%$ in the private sector.

Drawing on the ISCO occupational coding, we group workers into high, medium and low skill occupations based on the normal educational requirements of the job. ${ }^{6}$ The data show that the petroleum sector recruits more high skill workers. Within each worker origin group, the skill composition leans more towards high skilled jobs in petroleum compared to the private sector. Among native workers, $37.2 \%$ are in high skill jobs in petroleum versus $24.9 \%$ in the private sector. A striking finding to emerge from the table is that the difference across sectors is substantially larger for immigrants with $43.3 \%$ in high skilled occupations in the

\footnotetext{
${ }^{5}$ We exclude posted workers from this analysis because information on pay, occupation and education is not available for this group.

${ }^{6}$ High skill refers to occupations that normally require higher education (more than 3 years of tertiary education, professional occupations with ISCO first digit 2), medium skilled refers to jobs that normally require 1-3 years beyond upper secondary school (ISCO first digit 3), while low skill corresponds to upper secondary school (maximum 3-4 years beyond compulsory, ISCO first digit 4-9). We group managerial occupations (first digit 1) with the high skill category. Note that our 3-level classification reflects the distribution of occupational skill in the petroleum sector with the "low skill" group including many workers in skilled trade craft occupations.
} 
Table 2 - Worker characteristics by sector and migrant status. 2013.

\begin{tabular}{|c|c|c|c|c|c|c|}
\hline & $\begin{array}{l}\mathrm{Pe} \\
\text { Immigrants } \\
\text { (1) }\end{array}$ & $\begin{array}{l}\text { troleum sect } \\
\text { Temporary } \\
\text { migrants } \\
\text { (2) }\end{array}$ & $\begin{array}{c}\text { Natives } \\
\text { (3) }\end{array}$ & $\begin{array}{l}\text { Immigrants } \\
\text { (4) }\end{array}$ & $\begin{array}{l}\text { rivate secto } \\
\text { Temporary } \\
\text { migrants } \\
\text { (5) }\end{array}$ & $\begin{array}{c}\text { Natives } \\
(6)\end{array}$ \\
\hline Age & 39.5 & 42.9 & 43.5 & 38.7 & 39.3 & 43.6 \\
\hline $\begin{array}{l}\text { Female } \\
\text { Occupation }\end{array}$ & .233 & .030 & .204 & .337 & .114 & .370 \\
\hline High skill & .433 & .104 & .372 & .125 & .032 & .249 \\
\hline Medium skill & .336 & .181 & .234 & .112 & .097 & .224 \\
\hline Low skill & .231 & .715 & .394 & .764 & .872 & .527 \\
\hline Education & & na & & & $\mathrm{Na}$ & \\
\hline University (17+yrs) & .476 & & .185 & 147 & & .084 \\
\hline College (14-16) & .294 & & .319 & .250 & & .274 \\
\hline High school (13) & .142 & & .373 & .319 & & .367 \\
\hline Less than $\mathrm{HS}(<13)$ & .088 & & .123 & .285 & & .274 \\
\hline Foreign ownership & .446 & .712 & .441 & .200 & .205 & .203 \\
\hline Prior petro exper & & & & .015 & .032 & .031 \\
\hline Individuals & 9,888 & 3,405 & 61,227 & 211,845 & 39,596 & $1,000,183$ \\
\hline
\end{tabular}

Note: Samples are restricted to wage earners age 25-64. Occupation and education distributions are conditional on non-missing data. Occupation is missing for 7 and 2 percent of immigrants, 51 and 12 percent of temporary migrants, and 6 and 3 percent of native workers in the petroleum and other private sectors, respectively. Education is missing for 16 and 22 percent of the immigrants in the petroleum and other private sectors.

petroleum sector compared to only $12.5 \%$ elsewhere in the private sector. As a consequence, the immigrant native skill gap differs across industries. While immigrants are more skilled than natives in the petroleum sector, the pattern is reversed in other private-sector industries.

The skill distribution among temporary migrants in petroleum differs significantly from that of immigrants in the sector. About $72 \%$ of temporary migrants work in low skill occupations, compared to only $24 \%$ of (resident) immigrants. Yet, compared to temporary workers in the rest of the private sector, those in the petroleum sector hold jobs that require higher skills.

As immigrants often experience downgrading of their educational qualifications in the host country (Dustmann and Preston, 2012), skill distributions based on educational attainment may differ from those based on occupation classifications. In the petroleum sector we find 
fairly comparable skill distributions for immigrants whether based on occupational skill or educational attainment (see Table 2, column 1). However, a larger share of native workers with low educational attainment holds medium and high skill jobs. In the private sector, the pattern of downgrading arises for immigrant workers. Even if their educational attainment measured by years of schooling clearly outperforms that of natives (see columns 4 and 6 ), their occupation distribution is dominated by low skill jobs.

Foreign ownership is widespread in the petroleum sector. Fully $44.6 \%$ of immigrants and $44.1 \%$ of natives in the petroleum work in a company with foreign ownership, compared to $20 \%$ in the private sector. The extreme statistic is for temporary migrants in the petroleum sector, where almost three of four work in foreign-owned firms.

Wages in the petroleum sector are high. In Table 3, we report weekly pay by sector and occupational skill, separately for natives and immigrants. The petroleum sector pay premium is close to $100 \%$ for natives in low skill occupations. For natives in skilled occupations the petroleum premium is less extreme, but medium and high skilled petroleum workers on average nonetheless receive weekly pay that is $46 \%$ and $56 \%$ higher than in the private sector.

Table 3 - Weekly pay by occupational skill and immigrant status, petroleum vs. other private sector 2013.

\begin{tabular}{|c|c|c|c|c|}
\hline & \multicolumn{2}{|c|}{ Petroleum sector } & \multicolumn{2}{|c|}{ Private sector } \\
\hline & Immigrants & Natives & Immigrants & Natives \\
\hline \multicolumn{5}{|l|}{ Occupation } \\
\hline High skill & 2,954 & 2,626 & 1,536 & 1,685 \\
\hline Medium skill & 1,983 & 2,012 & 1,298 & 1,374 \\
\hline Low skill & 1,408 & 1,852 & 790 & 959 \\
\hline
\end{tabular}

Note: Table entry gives the average weekly pay in Euros within skill/immigrant/sector. Samples are restricted to wage earners age $25-64$.

Similar petroleum pay premiums are found for immigrants. Compared to private sector workers in the same occupation category, high skilled immigrants earn on average $92 \%$ more in petroleum. The premium is $52 \%$ for medium and $78 \%$ for low skill occupations. 
From Table 3, we also see that immigrant pay is lower than native pay within each occupation-sector cell, except for the high skill category in petroleum where average wages of immigrants exceed those of natives.

Exploring mechanisms behind the high petroleum pay premiums is beyond the scope of this paper. Along with that of productivity gains associated with high tech jobs, plausible explanations include rent sharing as profits are high (due to large resource rents). Bargaining power of workers is substantial from their ability to effectively impose losses on firms through industrial action. Marginal tax rates on firm profits exceed $90 \%$ in the petroleum sector, compared to $27 \%$ in the private sector.

In Table 4, we leave the petroleum sector wage premium and focus on the relative pay of foreign workers and report the immigrant-native log weekly pay gap within petroleum and private industries.

Each entry in Table 4 is the log weekly pay differential between immigrants and natives by broad occupation category, separately for each sector with varying sets of control variables across columns. Consider first the pay gaps in the private sector reported in columns (4)-(6). The unadjusted weekly pay gap relative to natives in column (4) is between 11 and 21\% depending on skill category. When we control for gender, age, tenure, educational attainment, foreign ownership and two-digit industry (i.e., 86 industry fixed effects), the estimated pay gap falls to between 5 and 12\% (see column 5). Differential sorting across firms appears to be equally important as differences in worker characteristics (Barth, Bratsberg, and Raaum 2012). In column (6), pay gaps are estimated within firms (i.e., with 117,410 firm fixed effects) and they turn out much lower, particularly for workers in medium and low skilled occupations. Within private sector firms, the gap between native and immigrant pay is between 3 and $6 \%$, depending on skill group.

Turning to the petroleum sector, immigrant-native pay gaps vary significantly across skill groups. Within the high skill bracket, immigrant pay is not significantly different from that of natives, whether or not we control for individual characteristics and firm fixed effects. 
Table 4 - Immigrant-native pay differentials within petroleum and private sectors, by occupation. 2013.

\begin{tabular}{|c|c|c|c|c|c|c|}
\hline & \multicolumn{3}{|c|}{ Petroleum sector } & \multicolumn{3}{|c|}{ Private sector } \\
\hline & (1) & (2) & (3) & (4) & (5) & (6) \\
\hline \multicolumn{7}{|l|}{ Occupation } \\
\hline \multirow[t]{2}{*}{ High skill } & .004 & -.001 & .001 & -.120 & -.077 & -.045 \\
\hline & $(.007)$ & $(.007)$ & $(.006)$ & $(.004)$ & $(.004)$ & $(.004)$ \\
\hline \multirow[t]{2}{*}{ Medium skill } & -.042 & -.019 & -.012 & -.105 & -.049 & -.032 \\
\hline & (.009) & (.008) & (.007) & $(.005)$ & $(.004)$ & $(.004)$ \\
\hline \multirow[t]{2}{*}{ Low skill } & -.283 & -.228 & -.121 & -.208 & -.124 & -.057 \\
\hline & (.010) & (.009) & $(.008)$ & $(.002)$ & $(.002)$ & $(.002)$ \\
\hline Observations & & 67,800 & & & $1,183,603$ & \\
\hline \#fixed effects & & 5 & 312 & & 86 & 117,410 \\
\hline Controls & Skill class & $\begin{array}{c}\text { Add } \\
\text { industry } \\
\text { fixed eff, } \\
\text { age, } \\
\text { tenure, } \\
\text { gender, } \\
\text { education, } \\
\text { for. owner }\end{array}$ & $\begin{array}{l}\text { Add firm } \\
\text { fixed } \\
\text { effects }\end{array}$ & Skill class & $\begin{array}{c}\text { Add } \\
\text { industry } \\
\text { fixed eff, } \\
\text { age, } \\
\text { tenure, } \\
\text { gender, } \\
\text { education, } \\
\text { for. owner }\end{array}$ & $\begin{array}{c}\text { Add firm } \\
\text { fixed } \\
\text { effects }\end{array}$ \\
\hline
\end{tabular}

Note: Standard errors are reported in parentheses. Samples are restricted to wage earners age 25-64.

Dependent variable is the log weekly wage.

Within medium skill occupations, immigrant pay is on average $4 \%$ lower than that of natives.

The estimated differential shrinks when we control for age, tenure, gender, education, education, foreign ownership and industry, and becomes insignificant when we compare immigrant and native workers in the same firm (see column 3).

Immigrant petroleum sector pay in low skill occupations is significantly lower than that of natives, but the differential of 0.28 log points is reduced by one fifth (to 0.23 ) when we control for age, tenure, gender, education, education, foreign ownership and detailed industry. Comparing workers within firms, the estimated pay gap is reduced even further to 12\%. Unlike immigrants with medium and high skilled jobs, low skilled immigrants do not receive similar pay to that of their native colleagues in comparable occupations working in the same firm.

To summarize the empirical results in Table 4, we find that, unlike in other private-sector industries, immigrants in high and medium skill occupations in the petroleum sector earn 
wages on par with natives, at least when we compare workers in the same firm. These skilled occupations cover fully 77\% of immigrant petroleum sector employment in 2013. While skilled immigrants are as likely to work in high paying firms as native workers in skilled occupations, immigrants in low skill jobs are more likely to work in low-paying firms than native petroleum workers in low-skill occupations. Immigrant workers in low skill jobs in the petroleum sector are much better paid than immigrants elsewhere in the private sector, but their petroleum sector premium is smaller than that of low-skill natives.

\section{Worker mobility}

\subsection{How long do foreign petroleum workers stay?}

As we have seen, a majority of the foreign workers in the petroleum sector are employed in high-skilled engineering occupations. The considerable pool of foreign talent contributes directly to productivity in the petroleum sector, and an important question is whether these workers also represent an asset to other private-sector industries. Prior research indicates that a strong presence of multinational companies has positive wage spillovers as workers with experience from multinationals move on to other firms or industries (Balsvik 2011; Poole 2013), and that worker mobility from high-tech firms raise wages of the workforce of their new employer (Møen 2007). Are there indications that the petroleum sector functions as a port of entry into the Norwegian private sector?

To answer this question, we decompose it into two parts: (1) What is the probability that a foreign worker remains in the Norwegian labor market over time, and how does the propensity to stay for the long haul vary across skill groups? And (2), conditional on staying in the Norwegian labor market, what is the probability that foreign workers will exit the petroleum sector and shift into other sectors of the economy? In section 6.3, we return to the second question along with the related issue of whether the petroleum experience boosts their wage in the private sector.

To begin, we first look at all foreign workers who appear in the petroleum sector without a prior history of income and wages in other Norwegian sectors. ${ }^{7}$ When interpreting this

\footnotetext{
${ }^{7}$ We restrict ourselves to foreign workers since the conditioning on having the first observed job in the petroleum sector has a different interpretation for natives. For a native, this would in fact be entry into the
} 
analysis by skill, however, we need to keep in mind that occupational data is only available from 2003 onwards, and that the reporting of occupation is somewhat incomplete. Also, the study period coincides with a period where the oil price, investments and employment were all growing, and where the composition of the foreign workforce shifted due to the eastwards expansions of the European Union in 2004 and 2007. This means that different sections of the survival curves are the result of different sets of cohorts that are recruited from different sets of countries under different phases of an investment boom: While someone entering the sector in 1992 can potentially be observed for a total of 22 years, someone entering the sample in 2009 can only be observed for four.

With these caveats in mind, Figure 8 shows the "survival" in the Norwegian labor market by years since their first entry for the three different categories of foreign workers with their initial job in the petroleum industry (Panel A) and other private-sector industries (Panel B). We find that, regardless of sector, about two thirds of the posted workers are gone from the Norwegian labor market within one year. For temporary migrants, the process takes a little longer - but about $60 \%$ are gone within two years. For immigrants, it takes around four years to reach the $50 \%$ mark in petroleum versus six years elsewhere in the private sector. In other words, immigrants in the petroleum sector have a greater propensity of to leave the country over time compared to those in the mainland economy. (The appendix shows, however, that the propensity to leave varies by arrival cohort, particularly for immigrants in the petroleum sector, and that differences across sectors are much smaller for immigrants who arrived after 2004.)

In Figure 9 we focus on those with immigrant status their first year in Norway, and examine their propensity to remain over time separately by occupational skill class. ${ }^{8}$ As the figure

\footnotetext{
labor market overall, as seen clearly in the conditioned sample: The average age for natives who enter the petroleum sector with no prior labor market experience is 18 while it is in the mid-thirties for all three categories of foreign workers.

${ }^{8}$ Recall that the survival curves by skill content of the initial job are restricted to the cohorts first observed between 2003 and 2012. Unfortunately, we lack data on initial occupation for about 20 percent in petroleum and 5 percent in the private sector, and mobility among those with missing data exceeds that of those with occupation data. For example, five years after entry 80 percent of the missing group in petroleum and 60 percent in the private sector had left the country, compared to about 40 percent of those with occupation data. We find no indication that the missing data problem affects our relative comparisons across skill categories, but note that our survival figures by skill overstate the true propensity to stay in Norway over time.
} 


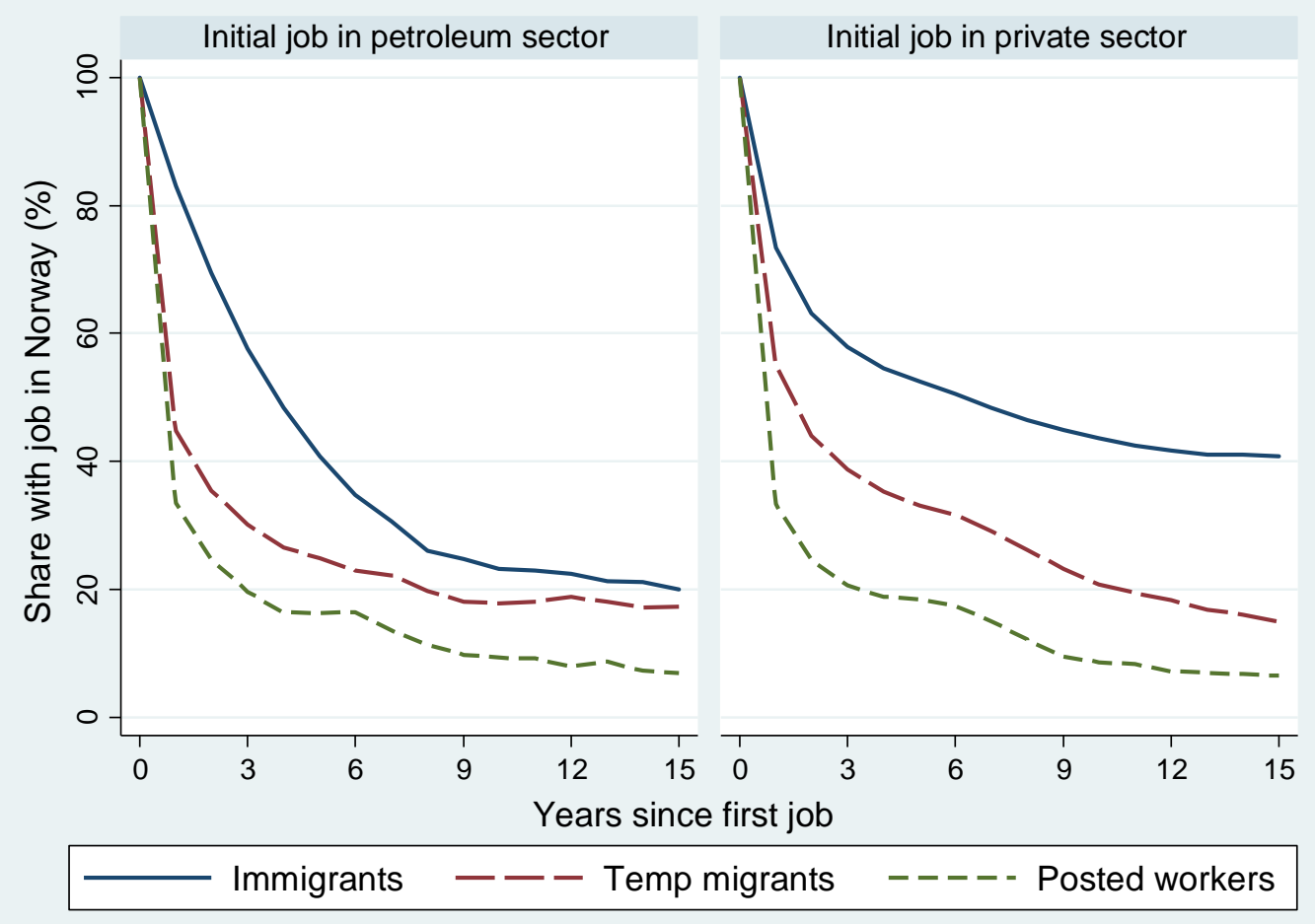

Figure 8 - Shares of foreign workers with continued employment in Norway by migrant status and years since first job

Note: Samples consist of foreign workers with first job in Norway between 1992 and 2012. Source: Authors' tabulations from register data

shows, after some years in the country private-sector outmigration propensities are quite similar across skill groups. In petroleum, however, the skill groups diverge after a few years with the workers in the lowest skill occupations being the most likely to stay for the long haul. Seven years after entering the Norwegian petroleum sector, $55 \%$ of the high-skilled group, which is dominated by engineers, have left the Norwegian labor market, compared to $33 \%$ of the low skilled group.

The finding in Figure 8 that immigrants, who at the time of arrival signal their intent to stay in Norway for an extended period, have longer durations of stay than temporary migrants and workers posted by their foreign employer, is hardly surprising. But, the finding in Figure 9 that immigrant workers in low-skill petroleum occupations have a higher propensity to 


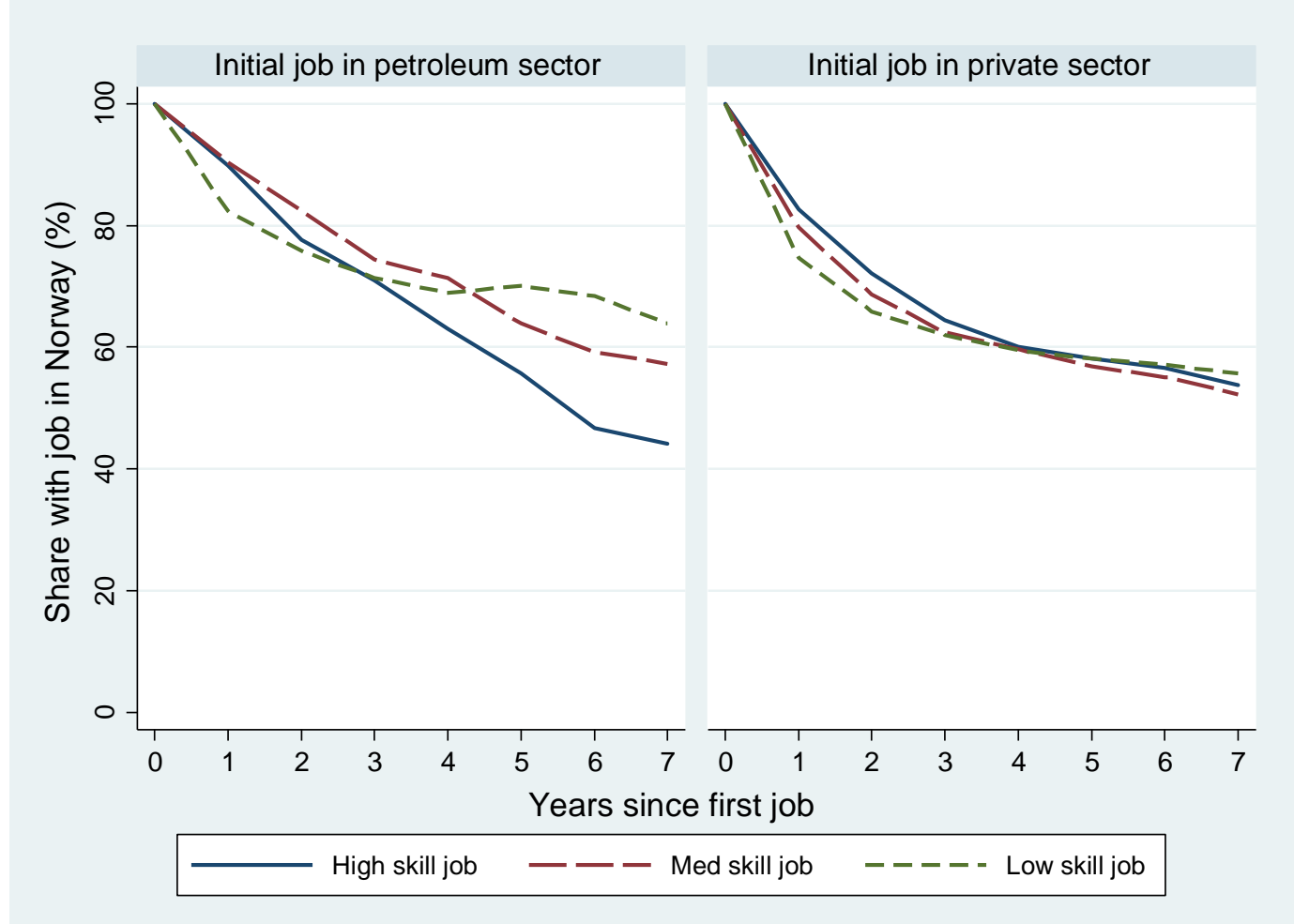

Figure 9 - Shares of immigrant workers with continued employment in Norway by occupational skill and years since first job

Note: Samples are limited to immigrant arrivals during 2003-2012 with occupation data; occupation is missing for $\mathbf{2 0}$ and $\mathbf{5}$ percent of the overall immigrant samples in petroleum and other private-sector industries, respectively. Source: Authors' tabulations from register data

remain in Norway over time than those in high-skill occupations may appear surprising in light of the analysis in the prior section showing that immigrants in low-skill occupations face significant wage penalties relative to native workers while high-skill foreign workers do not. The pattern is consistent, however, with predictions from migrant selection models such as Tunali (1986) and Borjas and Bratsberg (1996) if returns to skill are lower in the Norwegian labor market than in the source country. Given the more compressed wage structure in Norway than those found in the United Kingdom and continental Europe, such a scenario is plausible. With greater wage differentials by skill in the source country than in Norway, the expected wage loss associated with a return move is larger for workers in low-skill than highskill occupations, and the worker in the low-skill occupation has the greater economic incentive to remain in Norway. It is also worth noting that, even though immigrants in lowskill petroleum occupations face a significant wage penalty relative to native workers in the 
same occupations, their wages remain high relative to those of immigrants in low-skill occupations in other private-sector industries (see Table 2).

\subsection{Do temporary workers settle in the country?}

The prior section showed that, although outmigration rates are much higher among temporary migrants and posted workers compared to those with immigrant status at the time of their first job in Norway, many temporary and posted workers reappear with jobs in Norway even six years after their initial entry. This raises the question of whether such reappearances reflect circular migration patterns or whether foreign workers with temporary job contracts tend to settle in the country and adjust their status to that of immigrant (with residency). This question is addressed in Figure 10, which traces out the share of foreign workers with temporary status their initial year who adjust their migrant status over time.

As Figure 10 shows, the propensity of temporary migrants and posted workers to settle in Norway differs by sector of initial employment with those in the mainland sector far more likely to take up residency than those in the petroleum sector. In fact, six years after their first job more than half of those with temporary migrant status, and $40 \%$ of posted workers, in the mainland economy who remained in Norway had adjusted to immigrant status. Among those with initial employment in the petroleum sector, the equivalent adjustment rates lie between 10 and 20 percent. In other words, circular migration is far more common in the petroleum sector than in other private-sector industries. A final observation of interest is that many workers initially posted to Norway by a foreign employer over time find employment in a Norwegian registered firm; regardless of sector, six years after their initial posting 40 percent of those still in the country had switched to a job in a Norwegian company (see Figure 10, lower panels).

\subsection{Job transitions from petroleum to the mainland economy} The magnitude of spillovers from petroleum to the mainland depends on both the size of worker flows between sectors and the value of petroleum experience to firms in the private sector. In Figure 11 (left-hand panel) we plot the share of immigrants with initial 


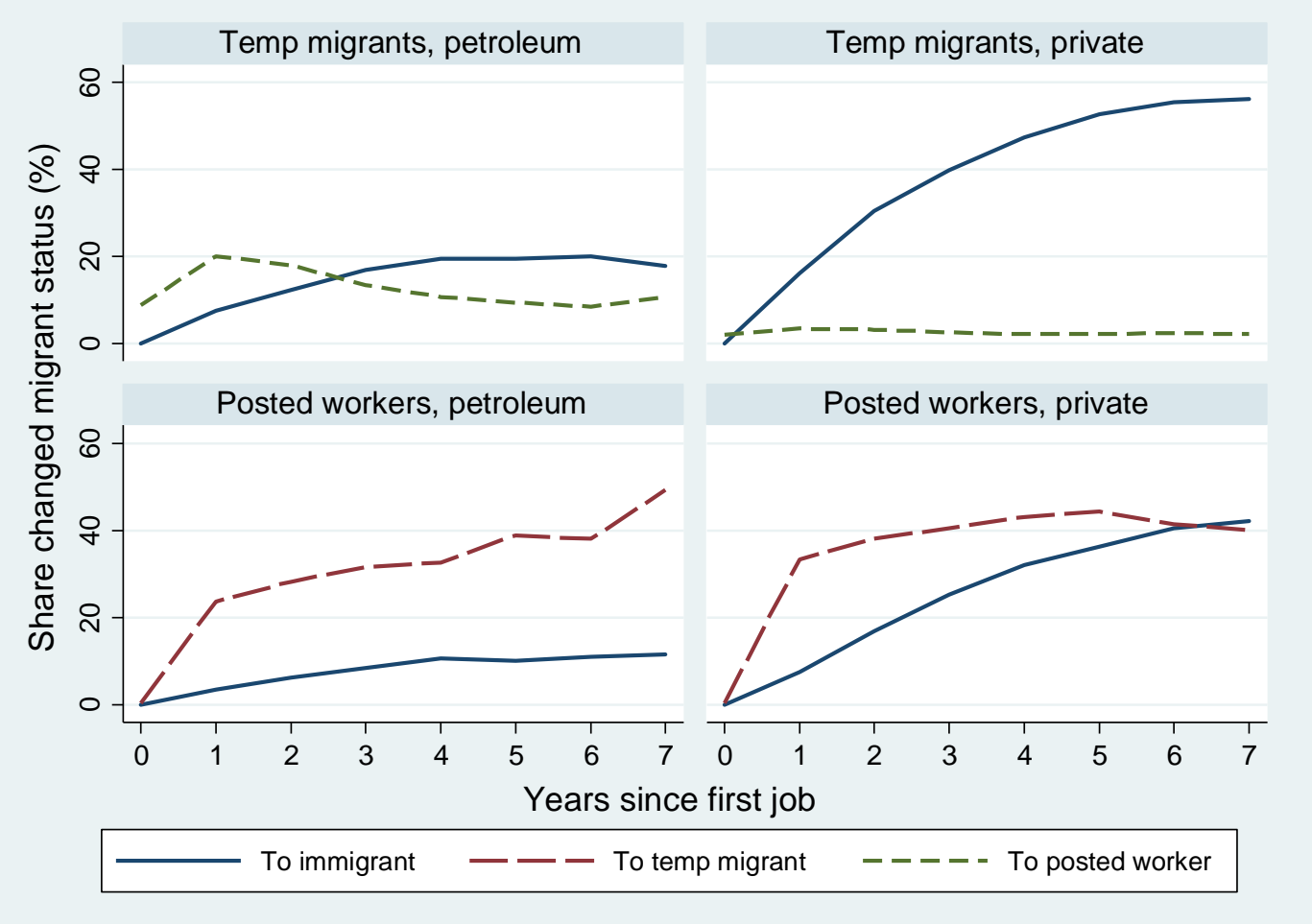

Figure 10 - Shares of temporary workers who change migrant status by initial sector of employment and years since first job

Note: Samples consist of temporary migrants and posted workers with first job in Norway between 1992 and 2012. Shares are conditional on continued employment in Norway. Source: Authors' tabulations from register data

employment in the petroleum sector who have switched to other private-sector (mainland) industries over time. The mobility out of petroleum differs significantly across skill groups. After 5 years, $60 \%$ of low skilled employees still in Norway had left the petroleum sector. Conversely, among medium and high skilled, more than $80 \%$ remained in the petroleum sector. The right-hand panel of the figure displays foreign labor mobility in the opposite direction, from the mainland economy to the petroleum sector. Not surprisingly, low skill mobility to petroleum is negligible. Immigrants with high-skill jobs are on the other hand more likely to find petroleum jobs. After 5 years, almost $10 \%$ of the medium and high skilled foreign private sector workers held jobs in the petroleum sector. 


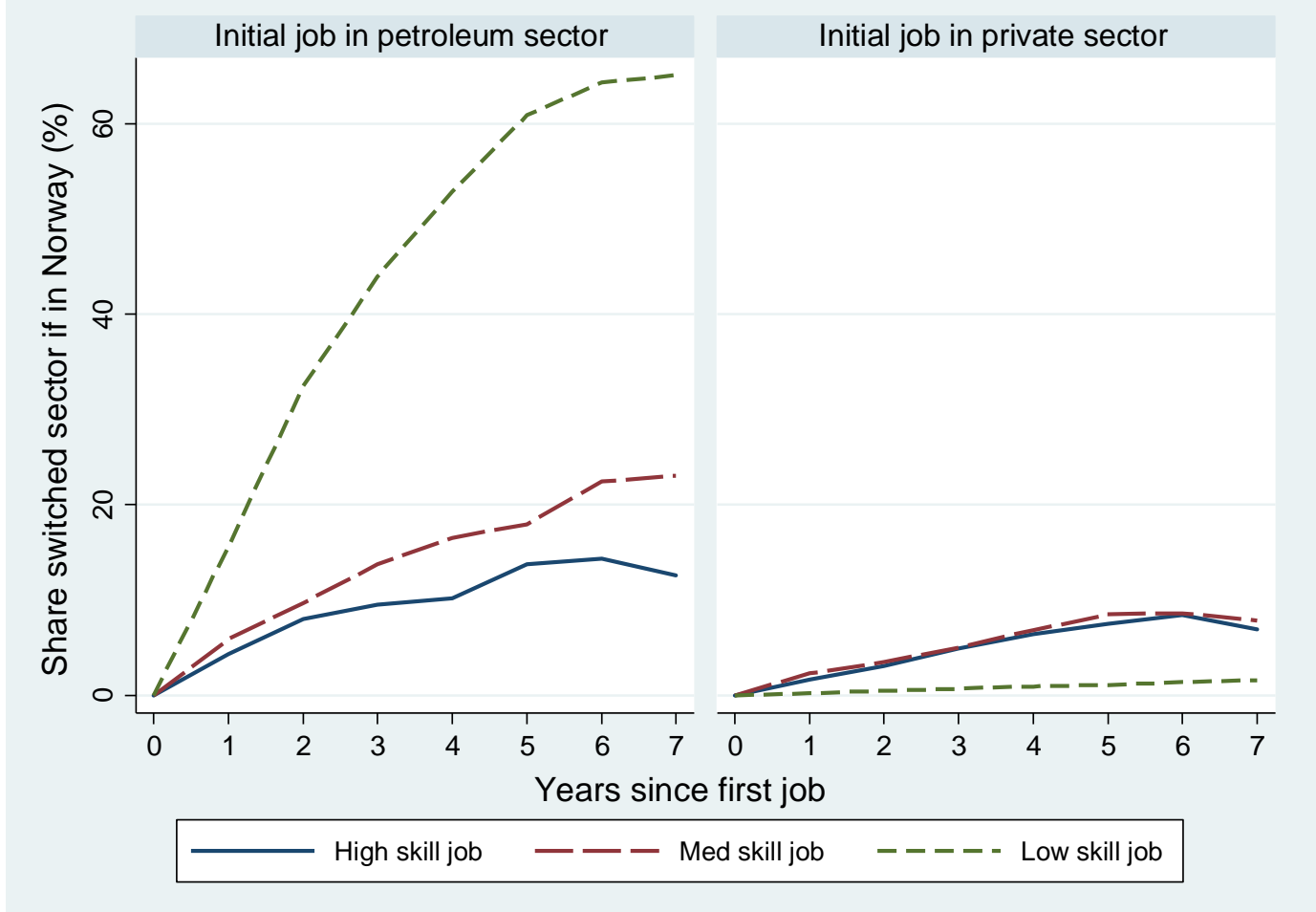

Figure 11 - Immigrant job mobility across sectors by skill content and sector of initial employment and years since first job

Note: Samples consist of foreign workers with first job in Norway between 2003 and 2012. Shares are conditional on continued employment in Norway. Source: Authors' tabulations from register data

Economic spillovers associated with worker mobility from petroleum to other sectors can be captured by individual workers, their new firms or colleagues. In this section we focus on wage returns for employees who move and estimate the premium for workers in the mainland economy who have prior petroleum sector experience. In Table 5, we report crosssectional private sector wage differentials between workers with and without petroleum sector experience, interacted with immigrant status.

For workers with no petroleum experience, the raw native-immigrant wage differential is about 0.3 log point, see column (1). While native workers with petroleum experience receive significantly higher pay than those without such experience $(0.350 \log$ point $)$, the returns to petroleum experience appear to be even larger for immigrants (an additional 0.246 log 
Table 5 - Returns to former petroleum experience for wage earners in the private sector. 2013.

\begin{tabular}{|c|c|c|c|c|}
\hline & (1) & $(2)$ & (3) & (4) \\
\hline Immigrant & $\begin{array}{l}-.301 \\
(.002)\end{array}$ & $\begin{array}{l}-.152 \\
(.002)\end{array}$ & $\begin{array}{l}-.106 \\
(.002)\end{array}$ & $\begin{array}{l}-.051 \\
(.002)\end{array}$ \\
\hline Petro experience & $\begin{array}{l}.350 \\
(.004)\end{array}$ & $\begin{array}{l}.209 \\
(.004)\end{array}$ & $\begin{array}{l}.156 \\
(.004)\end{array}$ & $\begin{array}{c}.052 \\
(.003)\end{array}$ \\
\hline Immigrant* petro exper & $\begin{array}{l}.246 \\
(.013)\end{array}$ & $\begin{array}{l}.138 \\
(.012)\end{array}$ & $\begin{array}{l}.114 \\
(.011)\end{array}$ & $\begin{array}{l}.034 \\
(.010)\end{array}$ \\
\hline $\begin{array}{l}\text { Observations } \\
\text { \#fixed effects }\end{array}$ & \multicolumn{4}{|c|}{$1,183,603$} \\
\hline Controls & None & $\begin{array}{l}\text { Add age, } \\
\text { tenure, gender, } \\
\text { education, } \\
\text { occupation skill, } \\
\text { for. owner }\end{array}$ & $\begin{array}{l}\text { Add industry } \\
\text { fixed effects }\end{array}$ & $\begin{array}{l}\text { Add firm fixed } \\
\text { effects }\end{array}$ \\
\hline
\end{tabular}

Note: Standard errors are reported in parentheses. Sample is restricted to wage earners age 25-64. Dependent variable is the log weekly wage. The sample contains 30,605 natives and 3,101 immigrants with prior experience from the petroleum sector (see also Table 2).

point). Consequently, the native-immigrant wage differential for private sector workers with petroleum experience is just $5.5 \%$ (or $0.301-0.246 \log$ point). While this pattern remains as we control for individual characteristics (column 2), and employer effects by industry (column 3) or firm (column 4), the size of the estimated wage differential drops considerably. As revealed by a comparison of columns ( 3 ) and (4), firm fixed effects are particularly important, suggesting that former petroleum experience give better access to high-paying firms in the mainland economy. For immigrants with no petroleum experience, the estimated wage gap relative to natives drops by one half when we compare workers within firms (column 3 vs 4), indicating that foreign workers are less likely than natives to work in high-paying firms (Barth et al 2012). Among those with petroleum experience, the evidence suggests similar patterns of sorting across mainland firms for immigrants and natives. As the estimated firm fixed effects reflect average wage residuals, the specification in column (4) might "over-control" as any spillovers from individuals to colleagues or firm productivity will be captured by the firm level controls. Nonetheless, the evidence that workers with experience from the petroleum sector earn a significant wage premium over similar workers 
even in the same firm is consistent with former petroleum workers bringing a productive advantage that is highly valued by their mainland employer. ${ }^{9}$

To shed light on the nature of the returns to petroleum experience, we next address heterogeneity in returns along three dimensions expected to capture accumulated human capital and productivity of the mover. In this, we examine whether the private-sector pay advantage of former petroleum workers depends on (1) years of experience in the petroleum sector; (2) the skill content of the petroleum job; and (3) the firm wage component of the past employer in the petroleum sector.

If experience raises individual productivity through human capital accumulation, the spillover effect should depend on the duration of the petroleum employment spell ("petroleum tenure"). In Table 6, columns (1) and (2), we find that the wage premium indeed depends on petroleum tenure (defining short durations of 1-2 years as the reference category). The estimated wage gain is increasing in duration with an additional wage differential of $3.4 \%$ for medium length (3-5 years) and $8.7 \%$ for long tenure (6 years plus). The estimated marginal wage premiums are very similar for immigrants and natives as only the main immigrant interaction term is significant. Again, we find evidence of sorting across firms in the private sector. With firm fixed effects (column 2), the returns to petroleum experience are increasing in duration but the estimates are smaller than those in column (1).

Accumulated human capital from the petroleum sector likely differs across petroleum jobs. Workers in high skilled occupations are expected to accumulate more knowledge than those performing simple tasks. In Table 6, columns (3) and (4), we find differential returns to petroleum experience by the skill content of the petroleum job. While experience from a low skilled petroleum job boosts the wage of native workers by .119 log point (with industry controls; see column 3$)$, the premium is $0.293(=0.119+0.174)$ log point for natives with high skill petroleum experience. Even when we compare workers within firms (column 4), returns

\footnotetext{
${ }^{9}$ The empirical pattern that estimated returns to petroleum experiences decline when we go from industry to firm fixed effects (i.e., from column 3 to column 4), is consistent both with the explanation that petroleum workers sort into high-paying firms and the explanation that petroleum workers raise productivity among coworkers (i.e., spillover effects).
} 
Table 6 - Extended specifications: Returns to former petroleum experience by years of experience, skill content of petroleum job and petroleum firm wage effect. 2013.

\begin{tabular}{|c|c|c|c|c|c|c|c|c|}
\hline & (1) & (2) & (3) & (4) & $(5)$ & (6) & (7) & (8) \\
\hline Immigrant & $\begin{array}{l}-.106 \\
(.002)\end{array}$ & $\begin{array}{l}-.051 \\
(.002)\end{array}$ & $\begin{array}{l}-.106 \\
(.002)\end{array}$ & $\begin{array}{l}-.051 \\
(.002)\end{array}$ & $\begin{array}{l}-.106 \\
(.002)\end{array}$ & $\begin{array}{l}-.051 \\
(.002)\end{array}$ & $\begin{array}{l}-.106 \\
(.002)\end{array}$ & $\begin{array}{l}-.051 \\
(.002)\end{array}$ \\
\hline Petro exper & $\begin{array}{l}.121 \\
(.005)\end{array}$ & $\begin{array}{l}.036 \\
(.005)\end{array}$ & $\begin{array}{l}.119 \\
(.007)\end{array}$ & $\begin{array}{l}.016 \\
(.007)\end{array}$ & $\begin{array}{l}.093 \\
(.006)\end{array}$ & $\begin{array}{l}.024 \\
(.005)\end{array}$ & $\begin{array}{l}.056 \\
(.009)\end{array}$ & $\begin{array}{l}-.012 \\
(.008)\end{array}$ \\
\hline $\begin{array}{l}\text { Immigrant*petro } \\
\text { exper }\end{array}$ & $\begin{array}{l}.123 \\
(.016)\end{array}$ & $\begin{array}{l}.033 \\
(.014)\end{array}$ & $\begin{array}{l}.048 \\
(.022)\end{array}$ & $\begin{array}{l}.014 \\
(.019)\end{array}$ & $\begin{array}{l}.079 \\
(.018)\end{array}$ & $\begin{array}{l}.022 \\
(.016)\end{array}$ & $\begin{array}{l}.053 \\
(.026)\end{array}$ & $\begin{array}{l}.008 \\
(.022)\end{array}$ \\
\hline $\begin{array}{l}\text { 3-5 yrs petro } \\
\text { exper }\end{array}$ & $\begin{array}{c}.034 \\
(.008)\end{array}$ & $\begin{array}{c}.022 \\
(.007)\end{array}$ & & & & & $\begin{array}{c}.029 \\
(.008)\end{array}$ & $\begin{array}{l}.018 \\
(.007)\end{array}$ \\
\hline $\begin{array}{l}\text { Immigrant*3-5 } \\
\text { yrs }\end{array}$ & $\begin{array}{l}.007 \\
(.026)\end{array}$ & $\begin{array}{l}.016 \\
(.023)\end{array}$ & & & & & $\begin{array}{l}.001 \\
(.026)\end{array}$ & $\begin{array}{l}.018 \\
(.023)\end{array}$ \\
\hline $\begin{array}{l}6 \text { yrs + petro } \\
\text { exper }\end{array}$ & $\begin{array}{c}.087 \\
(.008)\end{array}$ & $\begin{array}{l}.041 \\
(.008)\end{array}$ & & & & & $\begin{array}{c}.060 \\
(.008)\end{array}$ & $\begin{array}{l}.031 \\
(.008)\end{array}$ \\
\hline Immigrant*6 yrs+ & $\begin{array}{l}.009 \\
(.031)\end{array}$ & $\begin{array}{l}.014 \\
(.027)\end{array}$ & & & & & $\begin{array}{l}.027 \\
(.032)\end{array}$ & $\begin{array}{l}.028 \\
(.028)\end{array}$ \\
\hline $\begin{array}{l}\text { Petro exper from } \\
\text { medium skill jb }\end{array}$ & & & $\begin{array}{l}.121 \\
(.011)\end{array}$ & $\begin{array}{l}.076 \\
(.010)\end{array}$ & & & $\begin{array}{c}.096 \\
(.012)\end{array}$ & $\begin{array}{l}.069 \\
(.010)\end{array}$ \\
\hline $\begin{array}{l}\text { Immigrant*med } \\
\text { skill job }\end{array}$ & & & $\begin{array}{l}.085 \\
(.035)\end{array}$ & $\begin{array}{l}.026 \\
(.031)\end{array}$ & & & $\begin{array}{l}.060 \\
(.037)\end{array}$ & $\begin{array}{l}.020 \\
(.032)\end{array}$ \\
\hline $\begin{array}{l}\text { Petro exper from } \\
\text { high skill job }\end{array}$ & & & $\begin{array}{l}.174 \\
(.012)\end{array}$ & $\begin{array}{l}.103 \\
(.011)\end{array}$ & & & $\begin{array}{l}.126 \\
(.012)\end{array}$ & $\begin{array}{l}.085 \\
(.011)\end{array}$ \\
\hline $\begin{array}{l}\text { Immigrant*high } \\
\text { skill job }\end{array}$ & & & $\begin{array}{l}.073 \\
(.037)\end{array}$ & $\begin{array}{l}-.001 \\
(.033)\end{array}$ & & & $\begin{array}{l}.036 \\
(.041)\end{array}$ & $\begin{array}{l}.020 \\
(.032)\end{array}$ \\
\hline $\begin{array}{l}\text { Petro exper from } \\
\text { med wage firm }\end{array}$ & & & & & $\begin{array}{l}.082 \\
(.008)\end{array}$ & $\begin{array}{l}.032 \\
(.007)\end{array}$ & $\begin{array}{l}.086 \\
(.008)\end{array}$ & $\begin{array}{l}.030 \\
(.007)\end{array}$ \\
\hline $\begin{array}{l}\text { Immigrant*med } \\
\text { wage firm }\end{array}$ & & & & & $\begin{array}{l}.062 \\
(.024)\end{array}$ & $\begin{array}{l}.026 \\
(.021)\end{array}$ & $\begin{array}{l}.043 \\
(.028)\end{array}$ & $\begin{array}{l}.014 \\
(.024)\end{array}$ \\
\hline $\begin{array}{l}\text { Petro exper from } \\
\text { high wage firm }\end{array}$ & & & & & $\begin{array}{l}.144 \\
(.010)\end{array}$ & $\begin{array}{l}.075 \\
(.009)\end{array}$ & $\begin{array}{l}.150 \\
(.010)\end{array}$ & $\begin{array}{l}.069 \\
(.010)\end{array}$ \\
\hline $\begin{array}{l}\text { Immigrant*high } \\
\text { wage firm }\end{array}$ & & & & & $\begin{array}{c}.072 \\
(.038)\end{array}$ & $\begin{array}{l}.011 \\
(.033)\end{array}$ & $\begin{array}{l}.009 \\
(.040)\end{array}$ & $\begin{array}{l}-.014 \\
(.035)\end{array}$ \\
\hline Fixed effects & Industry & Firm & Industry & Firm & Industry & Firm & Industry & Firm \\
\hline
\end{tabular}


to petroleum experience is increasing in the skill level of the petroleum job. Without firm fixed effects, immigrants receive an additional premium for petroleum experience. Again, this premium relates to sorting across firms as it disappears when we compare workers within the same firm (as in column 4).

Finally, we examine whether private-sector returns to petroleum experience depend on which firm the mover worked for in the petroleum sector. To address this issue, we first stack together data for petroleum workers covering ten years (2003-2012) and estimate a log wage equation (with the usual controls of this and the prior section as well as year of observation and 2-digit occupation) in order to assess the firm fixed wage effect of each petroleum firm. Although not reported in tables, these estimates reveal considerable wage heterogeneity across petroleum firms, with a standard deviation of .229 log point when weighted by firm size. High paying firms are likely to be more productive due to their superior technology, management or market power, and a conjecture is that productivity components may be portable to other sectors. Next, we associate each former petroleum worker in the 2013 private sector data with the wage component of their prior employer, and classify ex-petroleum workers as coming from low, medium, or high paying petroleum firms. (The classification uses the $30^{\text {th }}$ and $70^{\text {th }}$ percentiles of the distribution of firm wage effects across petroleum workers, i.e., -.140 and .140 log point, as thresholds in the classification scheme.) In columns (5) and (6) we test whether the petroleum experience wage premium is associated with the wage component of the former employer. As the results show, the private sector wage premium is considerably larger for those who used to work for a high paying petroleum firm. Private-sector wages are strongly increasing in the petroleum-sector firm wage effect, consistent with greater productivity-related spillovers when such workers move to the mainland economy.

In the final columns of Table 6 we include all three dimensions reflecting petroleum-sector human capital accumulation; years of petroleum experience as well as heterogeneity of returns by job skill and firm wage effects. Even within private-sector firms, the evidence shows that there are positive marginal effects of years of petroleum experience, that returns are higher for workers coming from skilled petroleum jobs, and that the wage in the private sector relates positively to petroleum sector firm fixed effects. Including all three dimensions, 
returns to petroleum experience appear to be very similar for immigrants and natives who move to jobs in the mainland economy.

\section{Conclusions}

Employment in the Norwegian petroleum sector increased by $60 \%$ during the 2000 s from 50,000 employees during the 1990 s to more than 80,000 in 2013 , with the growth concentrated in firms within extraction services. While foreign labor in the petroleum sector has been common throughout our 22-year study period, the massive inflow of foreign workers since the $2004 \mathrm{EU}$ enlargement has been even more pronounced in other private sectors. By 2013, the foreign employment share is just below $20 \%$ in petroleum as well as elsewhere in the private sector.

Foreign employees in Norway consist of immigrants, temporary migrants without residency, and posted workers employed by firms based abroad. While immigrants constitute the majority of foreign workers, temporary migrants and posted workers are common in extraction services and petroleum related industries. In oil and gas extraction, foreign labor is dominated by immigrants with residency in Norway, as is the case in other private-sector industries.

In general, the petroleum sector recruitment is dominated by skilled labor and the positive skill selection into petroleum, compared to other private sector industries, is particularly strong among immigrants. About three of four immigrants in the petroleum sector hold high or medium skill jobs and equally many have tertiary educational qualifications, typically in engineering fields.

Wages in the petroleum sector are high and the weekly pay premium relative to the private sector varies between 50 and $100 \%$ across skill group and immigrant status. Typically, the petroleum-sector pay premium is larger for immigrants than for natives.

The immigrant-native pay differential in the petroleum sector varies across skill groups. When we compare immigrants and natives in skilled occupations within the same firm, average pay is the same. Immigrant petroleum sector pay in low skill occupations is, however, significantly lower than for natives even though the pay gap is reduced from 28 to $12 \%$ when we compare co-workers in the same occupation class employed by the same firm. 
Elsewhere in the private sector, estimated wage differentials between natives and immigrants working in the same firm vary from 3.2 to $5.7 \%$ across skill groups.

The magnitude of immigration spillovers from the petroleum sector will hinge on the extent to which foreign labor stay in Norway and move into the private sector. After four years, one half of the immigrants have left the country, and the propensity to leave is even higher for temporary migrants and posted workers. Return migration is also selective as immigrants in high skilled jobs are less likely to stay for the long haul. When it comes to job transitions, only $20 \%$ of the high skilled workers who stay move to jobs elsewhere in the private sector, compared to $60 \%$ of those in low skill jobs.

Finally, the existence of spillovers requires that workers who move bring valuable knowledge that is captured by themselves, colleagues or their employers. We find that workers in the mainland economy with petroleum experience earn a significant wage premium over similar workers with no petroleum experience, consistent with a productive advantage. Importantly, we uncover evidence that this petroleum-experience wage premium is increasing in the duration of petroleum experience as well as in the skill content of the job the mover held in the petroleum sector. We also find that the private sector wage premium of former petroleum workers relates positively to the firm-specific wage level of their former employer in petroleum.

Even if our findings show modest mobility rates of foreign workers from petroleum to the mainland economy, the robust empirical patterns of wage premiums received by workers who move suggest that movers carry a productive advantage that is highly valued by their mainland employer. The interpretation that the wage premium reflects productive advantage is bolstered by the findings that the premium is strictly increasing in human capital accumulation from the petroleum sector. Such evidence points to productive spillovers from foreign and native workers alike who move from the petroleum sector to jobs elsewhere in the economy. 


\section{References}

Allcott, Hunt, and Daniel Keniston. 2014. Dutch Disease or Agglomeration? The Local Economic Effects of Natural Resource Booms in Modern America. Working Paper 20508. National Bureau of Economic Research.

Balsvik, Ragnhild. 2011. "Is Labor Mobility a Channel for Spillovers from Multinationals? Evidence from Norwegian Manufacturing." The Review of Economics and Statistics 93 (1): 285-97.

Barth, Erling, Bernt Bratsberg, and Oddbjørn Raaum. 2012. "Immigrant Wage Profiles within and between Establishments." Labour Economics 19 (4): 541-56.

Beine, Michel, Serge Coulombe, and Wessel N. Vermeulen. 2015. "Dutch Disease and the Mitigation Effect of Migration: Evidence from Canadian Provinces." The Economic Journal forthcoming.

Bjørnland, Hilde C., and Leif A. Thorsrud. 2015. "Boom or Gloom? Examining the Dutch Disease in a Two-Speed Economy." The Economic Journal forthcoming.

Borjas, George, and Bernt Bratsberg. 1996. "Who Leaves? The Outmigration of the Foreign-Born." The Review of Economics and Statistics 78 (1): 165-76.

Bratsberg, Bernt, and Oddbjørn Raaum. 2012. "Immigration and Wages: Evidence from Construction." The Economic Journal, 12 2(565): 1177-1205.

Bruno, M., and J. Sachs. 1982. "Energy and Resource Allocation: A Dynamic Model of the 'Dutch Disease'." The Review of Economic Studies 49 (5): 845-59.

Cappelen, Ådne, Torbjørn Eika, and Joakim Prestmo. 2013. "Petroleumsvirksomhetens virkning på norsk økonomi og lønnsdannelse. Framtidig nedbygging og følsomhet for oljeprissjokk." Statistics Norway Reports 59/2013. Oslo, Norway: Statistics Norway. (https://www.ssb.no/nasjonalregnskap-og-konjunkturer/artikler-ogpublikasjoner/_attachment/151643?_ts=142b38e3a40)

Corden, W. Max, and J. Peter Neary. 1982. "Booming Sector and De-Industrialisation in a Small Open Economy." The Economic Journal 92 (368): 825-48.

Dustmann, Christian, and lan Preston. 2012. "Comment: Estimating the Effect of Immigration on Wages," Journal of the European Economic Association 10(1): 216-223.

Eika, Torbjørn, Joakim Prestmo, and Eivind Tveter. 2010. “Etterspørselen Fra Petroleumsvirksomheten - Betydningen for Produksjon Og Sysselsetting I Norge." Økonomiske Analyser, no. 3: 30-39.

Holden, Steinar. 2013. "Avoiding the Resource Curse the Case Norway." Energy Policy 63 (December): $870-76$.

Mehlum, Halvor, Karl Moene, and Ragnar Torvik. 2006. "Institutions and the Resource Curse." The Economic Journal 116 (508): 1-20.

Møen, Jarle. 2005. "Is Mobility of Technical Personnel a Source of R\&D Spillovers?" Journal of Labor Economics 23 (1): 81-114. doi:10.1086/jole.2005.23.issue-1.

Møen, Jarle. 2007. "R\&D spillovers from subsidized firms that fail. Tracing knowledge by following employees across firms," Research Policy, 36(9): 1443-1464.

Olsen, Trond E., and Petter Osmundsen. 2003. "Spillovers and International Competition for Investments." Journal of International Economics 59 (1): 211-38.

Poole, Jennifer P. 2013. "Knowledge Transfers from Multinational to Domestic Firms: Evidence from Worker Mobility." Review of Economics and Statistics 95 (2): 393-406.

Ryggvik, Helge. 2014. “Norsk oljehistorie.” Store norske leksikon. http://snl.no/Norsk_oljehistorie. 
Sachs, Jeffrey D., and Andrew M. Warner. 2001. "The Curse of Natural Resources." European Economic Review 45 (4-6): 827-38. doi:10.1016/\$0014-2921(01)00125-8.

Sandvik, Ole, and Jørgen Holck Johannesen. 2013. Sysselsatte I Petroleumsnæringene Og Relaterte Næringer 2011 (Employed in the Petroleum Industries and Related Industries 2011). Statistics Norway Reports 5/2013. Oslo, Norway: Statistics Norway. http://www.ssb.no/arbeid-oglonn/artikler-og-publikasjoner/_attachment/94817?_ts=13cce672620.

Tunali, Insan. 1986. "A General Structure for Models of Double-Selection and an Application to a Joint Migration/earnings Process with Remigration." Research in Labor Economics 8 (Part B): 23582.

\section{Appendix}

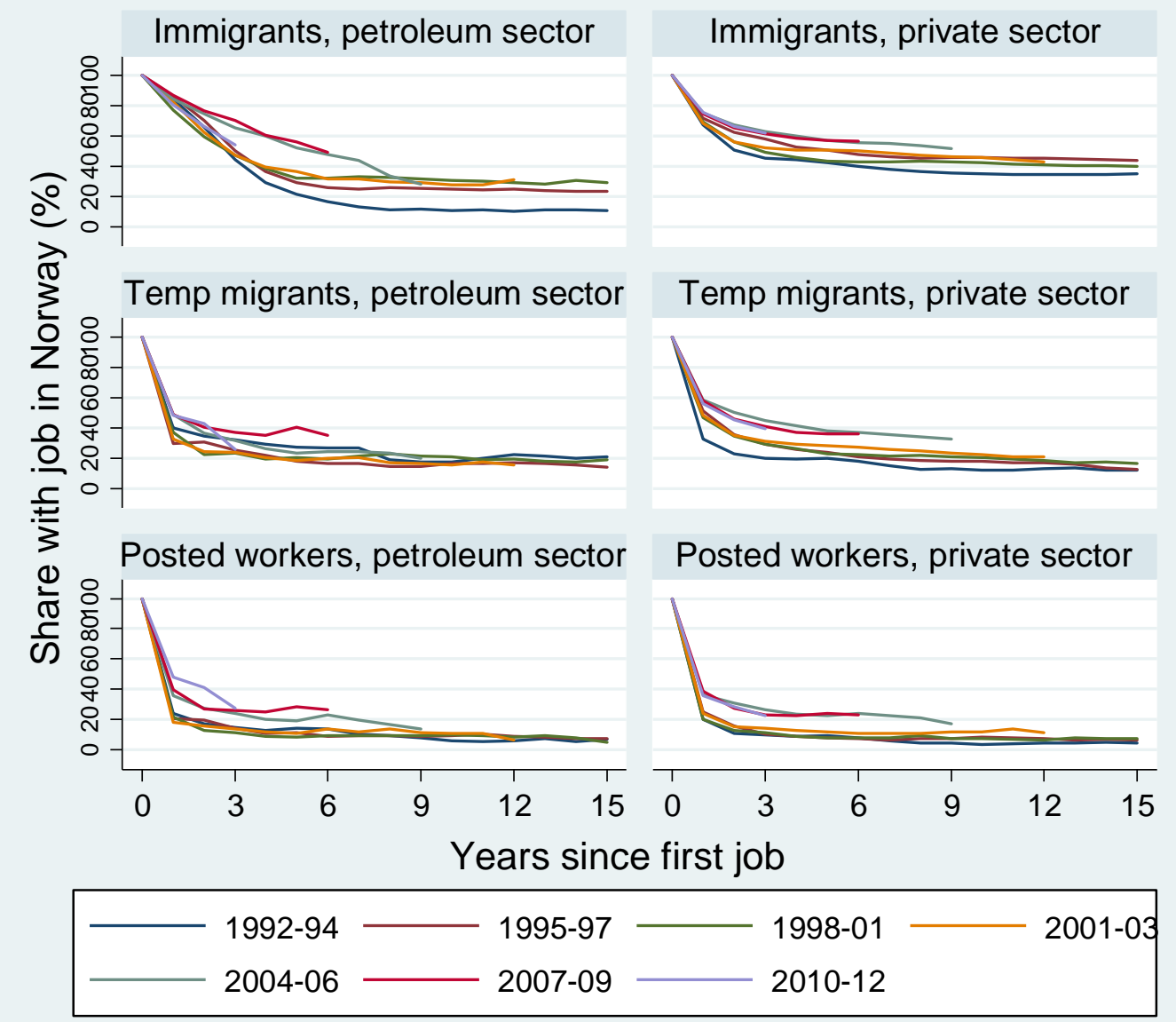

Figure A-1 - Arrival cohort differences in continued employment by migrant status and years since first job

Note: Samples consist of foreign petroleum workers with first job in Norway between 1992 and 2012. Source: Authors' tabulations from register data 